\title{
Farklı mineral ve tarımsal atık kaplamalı betonarme donatıların ve katkılı betonların korozyon performansının incelenmesi
}

\author{
Investigation of corrosion performance of different mineral and agricultural waste coated \\ reinforced concrete reinforcements and additive concrete
}

\author{
Mustafa EKEN*1.a \\ ${ }^{I}$ Kahramanmaraş İstiklal Üniversitesi. Elbistan Meslek Yüksekokulu. İnşaat Teknolojisi Bölümü. Kahramanmaraş/Elbistan
}

• Geliş tarihi / Received: 03.12.2020 • Düzeltilerek geliş tarihi / Received in revised form: 18.02.2021 • Kabul tarihi / Accepted: 08.03.2021

\section{$\ddot{O ̈ z}$}

Bu çalışmanın amacı; Donatı çubuklarını korozyon oluşumuna karşı korumada Mısır sapı külü (M), buğday sapı külü (B), ayçiçeği sapı külü (A) ve çınar yaprağı külleri (Ç) ile mineral katkılar olarak adlandırılan kolemanit (K), diatomit (D), yüksek firın cürufu $(\mathrm{Y})$, zeolit $(\mathrm{Z})$, uçucu kül $(\mathrm{U})$ ve bazaltik pomza $(\mathrm{P})$ katkılı kaplama malzemelerinin donatı korozyonuna karşı özelliklerinin incelenmesidir. Farklı katkılar kullanılarak tekli - ikili kombinasyonlarla beton örnekleri ve boya üretimi gerçekleştirilmiştir. Kaplama malzemesi olarak boya üretimi ve katkılı beton üretiminin gerçekleştirilebilmesi için laboratuvar ortamında elde edilen $\mathrm{M}, \mathrm{B}, \mathrm{A}$ ve Ç yaprağı küllerinin tekli karışımları çimento yerine kütlece $\% 10-\% 20-\% 30$ oranlarında ikili karışımları $\% 10-\% 30-\% 50$ oranlarında eklenmiştir. Mineral katkıların K, $\mathrm{D}, \mathrm{Y}, \mathrm{Z}, \mathrm{U}$ ve BP tekli karışımları ince agrega yerine kütlece \%10-\%20-\%30 oranlarında ikili karışımları ise \%10-\%30$\% 50$ oranlarında eklenmiştir. Çelik donatı dış yüzeyleri farklı mineral ve tarımsal atık katkılı boya ile kaplanırken, yine aynı katkılar kullanılarak beton üretimi gerçekleştirilmiştir. Donatı korozyonunun incelenmesinde dış yüzeyi kaplanmış donatılar katkılı betonlara gömülerek \%3.5'luk tuzlu su solüsyonunda bekletilmiş ve bu örneklere kütle kaybı yöntemi, galvanik hücre yöntemi ve hızlandırılmış korozyon deney yöntemleri uygulanmıştır. Çalışma sonuçları incelendiğinde donatı yüzeyi tarımsal atık katkılı M, B ve mineral katkııı K, U katkılı boyalarla kaplanan donatıların ve bu katkılarla üretilen beton örneklerin korozyona karşı göstermiş olduğu dirençler yüksek bulunmuştur. Farklı mineral katkılar ve tarımsal atıklar kullanılarak üretilen boya malzemesinin donatı korozyonunu önleyici kaplama malzemesi olarak kullanılması ve kullanılan tarımsal atıkların beton ve çimento sektöründe değerlendirilmesinde olumlu katkılar sağlayacaktır.

Anahtar kelimeler: Durabilite, Korozyon, Mineral katkılar, Tarımsal atıklar

\begin{abstract}
The aim of this study is; In protecting reinforcement bars against corrosion formation Corn stalk ash $(M)$, wheat stalk ash $(B)$, sunflower stalk ash $(A)$ and sycamore leaf ash $(C)$ and mineral additives called colemanite $(K)$, diatomite $(D)$, blast furnace Investigation of the properties of slag $(Y)$, zeolite $(Z)$, fly ash $(U)$ and basaltic pumice $(P)$ doped coating materials against reinforcement corrosion. Concrete samples and paint production were carried out with single and double combinations using different additives. As a coating material, for the production of paint and concrete with additives, the single mixtures of $M, B, A$ and Ç leaf ashes obtained in the laboratory were added in the ratio of $10-\% 20 \%$ $-30 \%$ by mass, double mixes at the rate of 10-\% 30-50\% instead of cement. Single mixtures of mineral additives $K, D, Y$, $Z, U$ and $B P$ were added at the rate of 10-\% 20\% -30\% by mass instead of fine aggregate, and double mixes at the rate of 10-\% 30-50\%, While the outer surfaces of the steel reinforcement were coated with paint with different mineral and agricultural waste additives, concrete was produced using the same additives. In the investigation of reinforcement corrosion, the outer surfaces of the coated reinforcements were embedded in concrete with additives and soaked in 3.5\% saline solution and mass loss method, galvanic cell method and accelerated corrosion test methods were applied to these samples. When the results of the study were examined, the resistance of the reinforcement surfaces coated with agricultural waste additive $M, B$ and mineral-added $K$, $U$-added paints and concrete samples produced with these additives against corrosion were found to be high. The use of paint material produced by using different mineral additives and agricultural wastes as a coating material to prevent reinforcement corrosion and the utilization of the used agricultural wastes in the concrete sector will provide positive contributions.
\end{abstract}

Keywords: Durability, Corrosion, Mineral additives, Agricultural waste

\footnotetext{
*a Mustafa EKEN; mustafaeken.me@gmail.com, Tel: (0506) 266 18 58, orcid.org/0000-0002-7559-876X
} 


\section{Giriş}

Betonarme, beton ve çelik gibi birbirine göre çok farklı ve zit iki malzemenin bir araya gelerek yap1 sisteminin temelini oluşturması olarak tanımlanmaktadır. Çevresel etkiler sonucunda betonarme fiziksel ve kimyasal olarak birçok durabilite problemleri ile karşı karşıya kalmaktadır. $\mathrm{Bu}$ etkiler içerisinde korozyon yapı bileşeninin servis ömrü ile doğrudan ilişkilidir ve durabilite problemlerinin en önemli parametrelerinden biri olarak kabul edilmektedir (Küçük, 2000; Yeau vd., 2005; Sakr, 2005; Baradan vd., 2005). Metallerin ortamda var olan oksijen ve nemim etkisiyle kimyasal veya elektrokimyasal reaksiyonlara girmesi sonucunda metallerin oksitlenerek kütle kaybına uğraması olayıdır (Baradan vd., 2005; Yalçın vd., 1999; Ergi vd., 2007), Beton içerisinde bulunan donatı korozyonu betonu oluşturan bileşenler, bileşenlerin durabilite özellikleri, pas payı, s / ç oranı, karışım oranları, betonun üretimi, betonun tasarımı, yapının bulunduğu ortam, çevre koşulları ve yapının servis ömrü gibi birçok faktöre bağlıdır (Ergi vd., 2007; Pavlik, 1996; Pavlik vd., 1997). Beton içerisine gömülü donatının korozyona karşı korunması betonun sahip olduğu alkali seviyesinin yüksek olmasindan kaynaklanmaktadır. Betonun mevcut $\mathrm{Ph}=13$ seviyesinde meydana gelen azalma donatının korozyona karşı korumasız kalacağının bir göstergesi olarak bilinmektedir. Beton içerisinde meydana gelen donatı korozyonu oluşumu bir diğer adıyla paslanma olarak da ifade edilmektedir. Paslanan donatı hacim artışına maruz kalarak gevrek özelliğe sahip betonun çatlaklar oluşturmasına neden olacaktır. Betonda meydana gelen çatlaklar betonu geçirimli hale getirerek diş etkilere maruz bırakır ve betonun servis ömrünü azaltmaktadır (Çil, 2006; Uysal, 2006).

Betonarme yapıların donatı korozyonuna karşı dirençli olmaları, yapı hizmet ömür sürelerinin artması ile atık malzemelerin geri dönüşümü, ekonomik açıdan elde edilen kazancın artması, sürdürebilirliğe katk1 sağlaması ve çevresel sorunların azalmasında yüksek pay sahibidir. Betonun geçirgenliği, beton içerisindeki mevcut boşlukların ve ara yüzeyde meydana gelen mikro çatlakların oluşturduğu durabilite sorunu oluşturan bir fonksiyondur. Özellikle donma-çözülmeye maruz kalan beton örneklerinde oluşacak çatlaklardan suyun içeriye nüfus ederek donması hacim genleşmesine neden olarak betonun geçirimliliği artacak korozyon oluşum riski hızlanacaktır. Durabilite özelliklerini geliştirmek korozyon dirençlerini arttırmak amacıyla farklı katkılar kullanılarak beton örnekleri elde edilmektedir (Yıldız vd., 2009). Bu katkılar çevre sorunu oluşturan kimyasal içerikleri ile beton örneklerinin performanslarını arttıran tarımsal atıklar ile endüstriyel ürünlerin atıklarını oluşturan malzemelerdir (Khatri vd., 2004; Sancak vd., 2014). Sürdürebilirliğin ve eko-verimliliğin sağlanmasında tarımsal atıkların kullanımı beton ve çimento sektöründe büyük önem arz etmektedir. Tarımsal atıklar kolay temin edilebilmeleri, nakliye giderlerinin azaltmaları, çevre kirliliğini minimize etmeleri, ekolojik döngü içerisinde tekrar yok edilebilmeleri ve yap1 ve malzemeleri üretiminde meydana gelen üretim giderlerini azaltmaları gibi birçok avantaj sağlamaktadırlar. Bu avantajlara sahip tarımsal atıklar birçok akademik çalışmada değerlendirilmiş ve başarıya ulaşılmıştır (Sisman vd., 2011; Binici vd., 2008, 2012; Aksoğan vd., 2016). Binici ve ark., yaptıkları çalışmada tarımsal atık olarak bulunan mısır, buğday ve ayçiçeği sapı küllerini çimentodan azaltarak beton örnekleri üretmişler, Elde ettikleri küllerle üretilen örneklerin betonun birçok durabilite problemlerini azaltmada etkin olduğu bunun yanı sıra radyasyon zırhlamada da normal betona oranla soğurma katsayısının yüksek olduğunu belirtmişlerdir. Farklı bir çalışmada ise, tarımsal atıklar ince agregadan azaltılarak ek puzolanik özellik ortaya çıkarmak hedeflememiştir, İnce agrega yerine kullanılan tarımsal atıklarla üretilen beton örneklerin işlenebilirliğe, mekanik özelliğe ve termal özelliklere katkıda bulunduğu belirtilmektedir (Oyedepo vd., 2014). Farkl1 mineral katkıların ince agrega yerine kullanılarak üretilen beton örneklerinde de betonun durabilite özellikleri gelişmiş ve performansı artmıştır (Demirbaş vd., 2000). Yapılan çalışmada durabilite problemlilerinden donatı korozyonuna karşı beton özelliklerini incelemek amaciyla katkılar kullanılarak beton üretimi gerçekleştirilmiş ve sonuçları incelendiğinde katkı kullanımının korozyon direncini arttırmada etkili olduğunu göstermektedir (Binici vd., 2012). Topçu ve arkadaşları granüle yüksek firın cüruf katkılı betonların korozyon direncini arttırıcı bir etkisi olduğunu zeolit katkılı betonların belirlemişleridir. Betonun dayanıklılık ve durabilite özelliklerini geliştirmek amacıyla zeolit ve pomza katkılarının kullanımı olumlu sonuçlar vermekte ve betonun geçirgenliği azaltmakta dolayısıla da korozyon oluşum riskini minimize etmektedir. Ayrıca dayanımı yüksek beton üretiminde diğer puzonlara alternatif bir malzeme olarak kullanılabileceği belirtilmektedir (Dorum vd., 2011; Y1ld1z vd., 2014). Yapılan literatür çalışmalarında zeolit, kolemanit, uçucu kül, pomza, diatomit gibi katkılar kullanılarak üretilen betonların donatı korozyonuna karşı dirençlerinin yüksek oldukları 
belirlenmiştir (Vesely vd., 2010; Najimi vd., 2012; Gerengi vd., 2015; Eskandari vd., 2015; Badar vd., 2014).

Ülkemiz deprem kuşağı bölgesinde yer almaktadır, 17 Ağustos Gölcük, 17 Ağustos 1999 Eskişehir'de ve 12 Kasım 1999 Düzce depremlerinden sonra yapılan hasar tespit çalışmaları mevcut binalarının \% 49'unda betonarme yapıların korozyon oluşumu nedeniyle donatılarda kesit daralmaları meydana geldiği görülmüştür. Meydana gele deprem etkilerinin yanında betonarme yapıların taşıma gücü kapasitesi için önemli bir parametre olan donatı korozyonunun oluşmaması için yapılarda beton katkı malzemesi kullanımı gibi birçok öneri sunulmuştur (Coşgun, 1999; Doğan 2000). İstanbul depremleri ile ilgili olarak yapılan araştırmalarda en büyük sorunun deprem olmadığ 1 korozyon olduğu belirlenmektedir (Coşgun, 2003). 24 Ocak 2020 Elazığ'da meydana gelen depremde yıkılan binalarda yapılan hasar tespit çalışmaları raporu korozyon oluşumu binaların taşıma gücü kapasitesini zayıflatmakta ve bunun sonucu olarak aderans kaybı ve bina yıkımları meydana gelmektedir (Çağlar vd., 2020).

$\mathrm{Bu}$ çalışmanın amac1, korozyon oluşumunu önlemek amaciyla teknolojik birçok yöntem bulunmaktadır, bu yöntemler arasında temin edilme süresi, uygulama kolaylığı, uygulama sonras1 kullanım ömrü, malzeme yüzeyinde geçirgenliği azaltması, ekonomikliği ve korozyonu önleme avantajları sayıldığında en etkili yöntemlerden biri olarak yüzey kaplama yöntemi belirtilmektedir. Türkiye mineral katkılar ve tarımsal açısında zengin bir ülke olarak bilinmektedir. $\mathrm{Bu}$ avantaj1 ile kolemanit $(\mathrm{K})$, diatomit (D), yüksek firın cürufu (Y), zeolit (Z), uçucu kül (U) ve bazaltik pomza katkılı ve mısır sapı külü (M), buğday sapı külü (B), ayçiçeği sapı külü (A) ve çınar yaprăğ külleri (Ç) gibi tarımsal atıklar kullanılarak donatı yüzeyinin kaplanması amacıyla boya üretimi gerçekleştirilmiştir. Ayrıca aynı katkıların tekli ve ikili kombinasyonları oluşturularak mineral katkılar ince agrega yerine, tarımsal atıklar ise çimento yerine kullanılarak beton örnekleri üretilmiştir. $\mathrm{Bu}$ şekilde farklı mineral katkılar ve tarımsal atıklar tekli ve ikili kombinasyonlarda kullanılarak beton kalitesi yüksek, geçirimliliği az, durabilite bakımında iyi beton üretimi gerçekleştirilecektir. Uygulanan korozyon yöntemlerinde elde edilen değerler ile malzemelerin optimum kullanım miktarları belirlenmiştir. Tarımsal atıklar ve sanayi yan ürün atıklarının değerlendirilmesi ile gelecek nesillerin çevresel, ekonomik ve sosyal açıdan kendi ihtiyaçlarını karşılamak için doğal kaynaklar korunması amaç edinilmiştir. Beton yapılar dünyadaki insanların zamanının büyük bir çoğunluğunu geçirdiği sosyal mekân olarak bilinmektedir. $\mathrm{Bu}$ oran dikkate alındığında yapı bileşenleri ve yapı malzemelerine verilen önemin büyüklügü ortaya çıkmaktadır. Ülkemizin deprem kuşağ 1 bölgesinde yer alması ve korozyon oluşumun yapılara verdiği zarar göz önüne alındığında çalışmada farklı katkılar ile üretilen beton örneklerinin sonuçları irdelendiğinde donatı korozyonunu önleyici etkilerin meydana geldiği kaydeder bir durumdur.

\section{Malzeme ve yöntem}

\subsection{Materyaller}

TS EN 197-1 standartlarına göre CEM I 42.5 R tipi çimento kullanılmaktadır. İnce agrega olarak 0-4 mm kum, iri agrega olarak 4-22.4 mm kalkerli kırmataş agregası kullanılmıştır. Agregaların özellikleri Tablo 1'de verilmektedir. Misır, buğday, ayçiçeği ve çınar yaprağ 1 Kahramanmaraş bölgesinde yaygın bulunan tarımsal atıklardır. Çalışmada kullanılan tarımsal atıklardan buğday sapı, tarım sektöründe çalışan çiftçilerin buğday hasatını tamamlamalarının ardından tarlada kalan kısmıdır. Çiftçilerin bir sonraki tarım ürününü ekmek için sorun oluşturan bu saplar toplanarak kapalı bir ortamda yakılmış ve aynı ortamda soğutularak külleri elde edilmiştir. Diğer bir tarımsal atık ürünü olan ayçiçeği sapı, ayçiçeği ürününün hasadı alındıktan sonra çiftçilere sorun oluşturan sap kısmıdır. Ayçiçeği sapı toplanarak kapalı bir ortamda yakılmış ve soğuma bırakılarak külleri elde edilmiştir. Mısır sapı tarımsal atığı, çiftçinin mısır hasadı yaptırmasından sonra tarlada atık malzeme olarak kalan kısmıdır. Kurallara uygun olarak toplanıp yakılarak külleri elde edilmiştir. Diğer bir tarımsal atık ürünümüz çınar yaprağı, şartlara uygun toplanıp yakıldıktan sonra külleri elde edilmiştir. $\mathrm{Bu}$ tarımsal ürünlerin kurallarına uygun olarak toplanıp küllerinin elde edilmesi bölge için ek istihdam alanlarının sağlanmasına da yardımcı olacaktır. Kolemanit Eti maden işletmelerinden, Diatomit Afyon bölgesinden, Yüksek firın cürufu İskenderun İsdemir AŞ'den, Zeolit Manisa bölgesinden, Uçucu kül Çatalağzı termik santralinden, Bazaltik pomza Osmaniye bölgesinden temin edilmiştir. Çalışmada beton örneklere gömülü olarak bulunan S420 çelik çubuğu $210 \mathrm{Mpa}$ elastisite modülüne sahip $12 \mathrm{~mm}$ çapında ve $60 \mathrm{~mm}$ uzunluğundadır. CEM I 42.5 $\mathrm{R}$ ve atıkların kimyasal özellikleri Tablo 2'de verilmiştir. Donatı korozyonunun kaplama malzemesi olarak kullanılan boya karışımı Kayseri bölgesinde bir fabrikaya 
hazırlatılmıştır ve boya içerikleri Tablo 3'te verilmektedir. Tarımsal atık ürünler tarlalardan hasat sonrasi toplanarak laboratuvar ortamında kurumaya birakıld1, daha sonra $60 \mathrm{dk}$ boyunca sabit sıcaklık değeri korunarak $600^{\circ} \mathrm{C}$ 'de yakıldı ve ardından yanma süresi kadar süre içinde soğumaya bırakılmıştır. Tane boyutu homojenliği için $1 \mathrm{~mm}$ lik eleklerden elenerek karışımda kullanıma hazır hale getirilmiştir.

Tablo 1. Agrega özellikleri

\begin{tabular}{clll}
\hline Özgül ağırlık $\left(\mathrm{g} / \mathrm{cm}^{3}\right)$ & 2.67 & 2.71 & 2.71 \\
\hline S1kışık birim ağırlık $\left(\mathrm{g} / \mathrm{cm}^{3}\right)$ & 2.03 & 1.92 & 1.92 \\
\hline Gevşek birim ağırlık $\left(\mathrm{g} / \mathrm{cm}^{3}\right)$ & 1.82 & 1.67 & 1.67 \\
\hline Su emme kapasitesi $(\%)$ & 1.19 & 0.63 & 0.64 \\
\hline
\end{tabular}

Tablo 2. Malzemelerin kimyasal özellikleri

\begin{tabular}{cccccccccccc}
\hline $\begin{array}{c}\text { Bileşenler } \\
\text { \% }\end{array}$ & Çimento & $\mathbf{M}$ & $\mathbf{B}$ & $\mathbf{A}$ & $\mathbf{C}$ & $\mathbf{K}$ & $\mathbf{D}$ & $\mathbf{Y F C}$ & $\mathbf{Z}$ & $\mathbf{U}$ & $\mathbf{B P}$ \\
\hline $\mathrm{SiO}_{2}$ & 20.03 & 35.60 & 43.53 & 4.98 & 20.65 & 4.0 & 79.56 & 37.89 & 62.17 & 56.80 & 41.42 \\
\hline $\mathrm{Al}_{2} \mathrm{O}_{3}$ & 4.84 & 9.58 & 0.26 & 1.23 & 5.62 & 0.4 & 6.54 & 10.29 & 9.76 & 24.1 & 12.97 \\
\hline $\mathrm{Fe}_{2} \mathrm{O}_{3}$ & 2.42 & 3.67 & 0.58 & 0.63 & 3.4 & 0.08 & 2.76 & 0.95 & 2.02 & 6.8 & 11.41 \\
\hline $\mathrm{CaO}$ & 62.45 & 19.66 & 5.19 & 19.54 & 38.15 & 26.0 & 2.45 & 35.86 & 1.43 & 1.04 & 13.73 \\
\hline $\mathrm{MgO}$ & 2.61 & 2.23 & 0.99 & 4.22 & 1.72 & 3.0 & 0.79 & 7.38 & 0.75 & 2.4 & 7.76 \\
\hline $\mathrm{MnO}$ & - & 0.09 & 0.05 & 0.03 & 0.07 & - & - & - & - & - & - \\
\hline $\mathrm{K}_{2} \mathrm{O}$ & 0.8 & 1.62 & 14.82 & 34.68 & 1.05 & 0.17 & 0.69 & 0.9 & 3.72 & - & - \\
\hline $\mathrm{TiO}_{2}$ & - & 0.81 & 0.13 & 0.38 & 0.47 & - & - & - & - & 1.2 & - \\
\hline $\mathrm{Cr}_{2} \mathrm{O}_{3}$ & - & 0.02 & 0.002 & 0.003 & 0.02 & - & - & - & - & 1.92 & - \\
\hline $\mathrm{SO}_{3}$ & 3.55 & 0.04 & 0.39 & 0.92 & 0.13 & - & 0.48 & - & 0.07 & 2.9 & - \\
\hline $\mathrm{Na}_{2} \mathrm{O}$ & 0.6 & 0.25 & 0.97 & 0.26 & 0.3 & 0.18 & 2.63 & 0.6 & 0.46 & - & - \\
\hline $\mathrm{B}_{2} \mathrm{O}_{3}$ & - & - & - & - & - & 40 & - & - & - & - & - \\
\hline $\mathrm{Diğg}_{\mathrm{gig}}$ & 2.7 & 26.43 & 33.08 & 33.47 & 28.42 & 26.17 & 4.1 & 6.13 & 19.62 & 2.84 & 12.72 \\
\hline
\end{tabular}

Tablo 3. Boya karışım içerikleri

\begin{tabular}{lll}
\hline Malzeme & Miktar $\mathbf{( g )}$ & Yüzde (\%) \\
\hline Su & 4200 & 21.00 \\
\hline Calcon & 30 & 0.15 \\
\hline Zehir & 30 & 0.15 \\
\hline Islatıcı & 30 & 0.15 \\
\hline Glikol & 50 & 0.25 \\
\hline Amonyak & 40 & 0.20 \\
\hline Peva & 2800 & 14.00 \\
\hline Titan & 2600 & 13.00 \\
\hline Tarımsal atık küller ve mineraller & 5000 & 25.00 \\
\hline Kalsit (25 micron) & 4400 & 22.00 \\
\hline Aliminyumsilikat & 250 & 1.25 \\
\hline Talk & 400 & 2.00 \\
\hline Natrason & 70 & 0.35 \\
\hline Tiner & 100 & 0.50 \\
\hline Toplam & 20000 & 100 \\
\hline
\end{tabular}




\subsection{Karışım oranları}

Laboratuvar ortamında elde edilen Mısır sapı külü $(\mathrm{M})$, buğday sapı külü $(\mathrm{B})$, ayçiçeği sapı külü (A) ve çınar yaprağ 1 külleri (Ç) ağırlıkça $\mathrm{M}, \mathrm{B}, \mathrm{A}$ ve Ç yaprağı küllerinin tekli karışımları çimento yerine kütlece \%10-\%20-\%30 oranlarında, ikili karışımları MB, BA, AM, ÇM, AÇ ve BÇ \%10$\% 30-\% 50$ oranlarında isimlendirilerek beton tasarım yapılmıştır. Mineral katkıların D, Y, Z, U ve BP tekli karışımları ince agrega yerine kütlece $\% 10-\% 20-\% 30$ oranlarında hazırlanırken, ikili karışımları UD, DP, PY, ZK ve KU ise \%10-\%30$\% 50$ oranlarında isimlendirilerek beton tasarım yapılmıştır sadece K katkılı karışım için tekli ve ikili karışım oranları \%1-\%2-\%3 kullanılmaktadır. Bor içerikli karışımlar ile ilgili yapılan çalışmalarda betonun hidratasyon özelliğini geciktirici etki yaratmasında kaynaklandığı belirlenmiştir (Yalçın, 1996). Tarımsal atıklar ve mineral katkılar kullanılarak elde edilen beton örneklerin tekli karışım oranları Tablo 4'te İkili karışım oranları ise Tablo 5'te verilmektedir.

Tablo 4. Tekli karışım oranları

\begin{tabular}{|c|c|c|c|c|c|c|c|c|c|c|c|c|c|c|}
\hline & 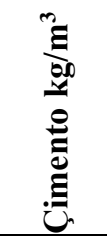 & 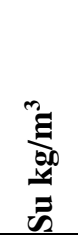 & 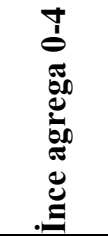 & 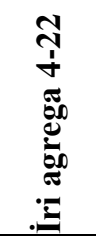 & 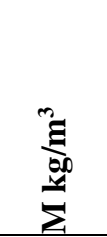 & 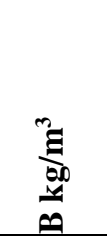 & 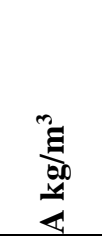 & 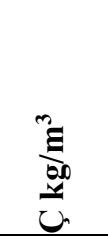 & 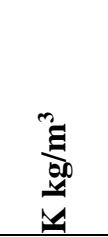 & $\frac{3}{a}$ & 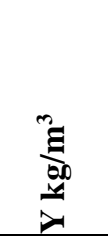 & $\underset{\mathbf{N}}{\mathfrak{N}}$ & 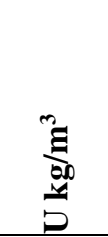 & 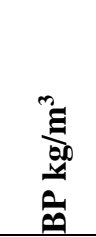 \\
\hline $\mathrm{R}$ & 397 & 200 & 671 & 1006 & - & - & - & - & - & - & - & - & - & - \\
\hline M10 & 357.3 & 200 & 671 & 1006 & 39.7 & - & - & - & - & - & - & - & - & - \\
\hline M20 & 317.6 & 200 & 671 & 1006 & 79.4 & - & - & - & - & - & - & - & - & - \\
\hline M30 & 277.9 & 200 & 671 & 1006 & 119.1 & - & - & - & - & - & - & - & - & - \\
\hline B10 & 357.3 & 200 & 671 & 1006 & - & 39.7 & - & - & - & - & - & - & - & - \\
\hline B20 & 317.6 & 200 & 671 & 1006 & - & 79.4 & - & - & - & - & - & - & - & - \\
\hline B30 & 277.9 & 200 & 671 & 1006 & - & 119.1 & - & - & - & - & - & - & - & - \\
\hline A10 & 357.3 & 200 & 671 & 1006 & - & - & 39.7 & - & - & - & - & - & - & - \\
\hline A20 & 317.6 & 200 & 671 & 1006 & - & - & 79.4 & - & - & - & - & - & - & - \\
\hline A30 & 277.9 & 200 & 671 & 1006 & - & - & 119.1 & - & - & - & - & - & - & - \\
\hline Ç10 & 357.3 & 200 & 671 & 1006 & - & - & - & 39.7 & - & - & - & - & - & - \\
\hline Ç20 & 317.6 & 200 & 671 & 1006 & - & - & - & 79.4 & - & - & - & - & - & - \\
\hline Ç30 & 277.9 & 200 & 671 & 1006 & - & - & - & 119.1 & - & - & - & - & - & - \\
\hline $\mathrm{K} 1$ & 397 & 200 & 603.9 & 1006 & - & - & - & - & 6.71 & - & - & - & - & - \\
\hline $\mathrm{K} 2$ & 397 & 200 & 536.8 & 1006 & - & - & - & - & 13.42 & - & - & - & - & - \\
\hline $\mathrm{K} 3$ & 397 & 200 & 469.7 & 1006 & - & - & - & - & 20.13 & - & - & - & - & - \\
\hline D10 & 397 & 200 & 603.9 & 1006 & - & - & - & - & - & 6.71 & - & - & - & - \\
\hline D20 & 397 & 200 & 536.8 & 1006 & - & - & - & - & - & 13.42 & - & - & - & - \\
\hline D30 & 397 & 200 & 469.7 & 1006 & - & - & - & - & - & 20.13 & - & - & - & - \\
\hline Y10 & 397 & 200 & 603.9 & 1006 & - & - & - & - & - & - & 6.71 & - & - & - \\
\hline Y20 & 397 & 200 & 536.8 & 1006 & - & - & - & - & - & - & 13.42 & - & - & - \\
\hline Y30 & 397 & 200 & 469.7 & 1006 & - & - & - & - & - & - & 20.13 & - & - & - \\
\hline $\mathrm{Z} 10$ & 397 & 200 & 603.9 & 1006 & - & - & - & - & - & - & - & 6.71 & - & - \\
\hline $\mathrm{Z} 20$ & 397 & 200 & 536.8 & 1006 & - & - & - & - & - & - & - & 13.42 & - & - \\
\hline $\mathrm{Z30}$ & 397 & 200 & 469.7 & 1006 & - & - & - & - & - & - & - & 20.13 & - & - \\
\hline $\mathrm{U} 10$ & 397 & 200 & 603.9 & 1006 & - & - & - & - & - & - & - & - & 6.71 & - \\
\hline U20 & 397 & 200 & 536.8 & 1006 & - & - & - & - & - & - & - & - & 13.42 & - \\
\hline U30 & 397 & 200 & 469.7 & 1006 & - & - & - & - & - & - & - & - & 20.13 & - \\
\hline BP10 & 397 & 200 & 603.9 & 1006 & - & - & - & - & - & - & - & - & - & 6.71 \\
\hline BP20 & 397 & 200 & 536.8 & 1006 & - & - & - & - & - & - & - & - & - & 13.42 \\
\hline BP30 & 397 & 200 & 469.7 & 1006 & - & - & - & - & - & - & - & - & - & 20.13 \\
\hline
\end{tabular}


Tablo 5. İkili karışım oranları

\begin{tabular}{|c|c|c|c|c|c|c|c|c|c|c|c|c|c|c|}
\hline & 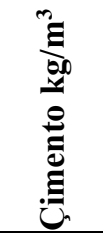 & 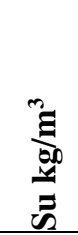 & 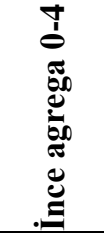 & 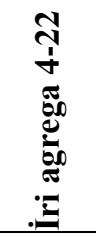 & 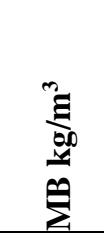 & 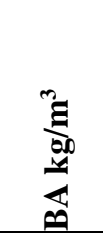 & 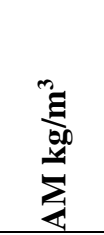 & D & 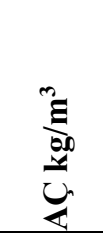 & 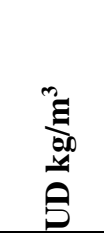 & 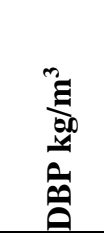 & 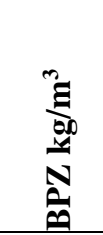 & 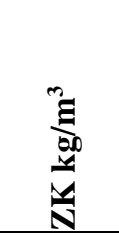 & 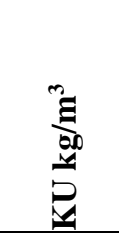 \\
\hline $\mathrm{R}$ & 397 & 200 & 671 & 1006 & - & - & - & - & - & - & - & - & - & - \\
\hline MB10 & 357.3 & 200 & 671 & 1006 & 39.7 & - & - & - & - & - & - & - & - & - \\
\hline MB30 & 277.9 & 200 & 671 & 1006 & 119.1 & - & - & - & - & - & - & - & - & - \\
\hline MB50 & 198.5 & 200 & 671 & 1006 & 198.5 & - & - & - & - & - & - & - & - & - \\
\hline BA10 & 357.3 & 200 & 671 & 1006 & - & 39.7 & - & - & - & - & - & - & - & - \\
\hline BA30 & 277.9 & 200 & 671 & 1006 & - & 119.1 & - & - & - & - & - & - & - & - \\
\hline BA50 & 198.5 & 200 & 671 & 1006 & - & 198.5 & - & - & - & - & - & - & - & - \\
\hline AM10 & 357.3 & 200 & 671 & 1006 & - & - & 39.7 & - & - & - & - & - & - & - \\
\hline AM30 & 277.9 & 200 & 671 & 1006 & - & - & 119.1 & - & - & - & - & - & - & - \\
\hline AM50 & 198.5 & 200 & 671 & 1006 & - & - & 198.5 & - & - & - & - & - & - & - \\
\hline ÇM10 & 357.3 & 200 & 671 & 1006 & - & - & - & 39.7 & - & - & - & - & - & - \\
\hline ÇM30 & 277.9 & 200 & 671 & 1006 & - & - & - & 119.1 & - & - & - & - & - & - \\
\hline ÇM50 & 198.5 & 200 & 671 & 1006 & - & - & - & 198.5 & - & - & - & - & - & - \\
\hline AÇ10 & 357.3 & 200 & 671 & 1006 & - & - & - & - & 39.7 & - & - & - & - & - \\
\hline AÇ30 & 277.9 & 200 & 671 & 1006 & - & - & - & - & 119.1 & - & - & - & - & - \\
\hline AÇ50 & 198.5 & 200 & 671 & 1006 & - & - & - & - & 198.5 & - & - & - & - & - \\
\hline UD10 & 397 & 200 & 603.9 & 1006 & - & - & - & - & - & 67.1 & - & - & - & - \\
\hline UD30 & 397 & 200 & 469.7 & 1006 & - & - & - & - & - & 201.3 & - & - & - & - \\
\hline UD50 & 397 & 200 & 335.5 & 1006 & - & - & - & - & - & 335.5 & - & - & - & - \\
\hline DBP10 & 397 & 200 & 603.9 & 1006 & - & - & - & - & - & - & 67.1 & - & - & - \\
\hline DBP30 & 397 & 200 & 469.7 & 1006 & - & - & - & - & - & - & 201.3 & - & - & - \\
\hline DBP50 & 397 & 200 & 335.5 & 1006 & - & - & - & - & - & - & 335.5 & - & - & - \\
\hline BPY10 & 397 & 200 & 603.9 & 1006 & - & - & - & - & - & - & - & 67.1 & - & - \\
\hline BPY30 & 397 & 200 & $\begin{array}{l}469.7 \\
\end{array}$ & 1006 & - & - & - & - & - & - & - & 201.3 & - & - \\
\hline BPY50 & 397 & 200 & 335.5 & 1006 & - & - & - & - & - & - & - & 335.5 & - & - \\
\hline ZK10 & 397 & 200 & 603.9 & 1006 & - & - & - & - & - & - & - & - & 36.9 & - \\
\hline ZK30 & 397 & 200 & 469.7 & 1006 & - & - & - & - & - & - & - & - & 110.71 & - \\
\hline ZK50 & 397 & 200 & 335.5 & 1006 & - & - & - & - & - & - & - & - & 169.52 & - \\
\hline KU10 & 397 & 200 & 603.9 & 1006 & - & - & - & - & - & - & - & - & - & 36.9 \\
\hline KU30 & 397 & 200 & 469.7 & 1006 & - & - & - & - & - & - & - & - & - & 110.71 \\
\hline KU50 & 397 & 200 & 335.5 & 1006 & - & - & - & - & - & - & - & - & - & 169.52 \\
\hline
\end{tabular}

\subsection{Test programı}

Deneyde kullanılmak üzere $12 \mathrm{~mm}$ çapında S420 sınıfi nervürlü betonarme çeliği, her biri $60 \mathrm{~mm}$ boyunda olacak şekilde kesilmiş ve kenarlarında oluşan çapaklar görüldüğü biçimde temizlenmiştir. Daha sonra donatılar dış yüzeylerinde oluşan pas tabakasının temizlenmesi için \%3 hidroflorik asit çözeltisinde bekletilmiş ve hemen alınarak diş yüzeyi kurulanmıştır. Çelik çubuklar değişmez ağırlığa gelinceye ve son ağırlık kaydedilmiştir. Boyutları ayarlanan çelik çubuklar daha önceden hazırlanmış olan boyalara daldırma yöntemi uygulanarak tek kat olarak kaplanmıştır (Şekil 1). 


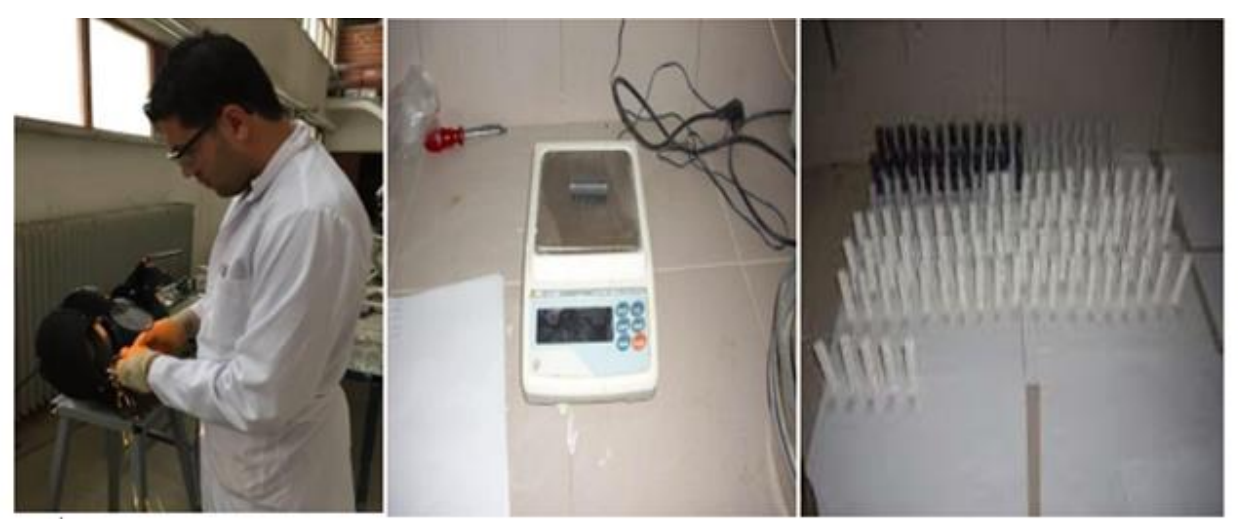

Şekil 1. $60 \mathrm{~mm}$ boyunda kesilen donatıların çapaklarının kesilmesi, tartım yapılması ve tek kat daldırma yöntemi uygulaması

Donatı korozyonu ölçüm aşamaları üç farklı deney yöntemi ile gerçekleştirilmiştir:

a) Hızlandırılmış Korozyon Deneyi: Donatı çubukların korozyon direncini kısa süre içerisinde belirlemek amaciyla kullanılan yöntemdir (Abouhussien, 2014; Maaddawy vd., 2003). Beton örnekler hazırlanan \%3.5 NaCl çözeltisinde sabit $30 \mathrm{~V}$ gerilime maruz bırakılmaktadır (Binici vd., 2012; Maaddawy vd., 2003).

b) Kütle Kaybı Deneyi: Korozyon oluşumu nedeniyle donatı çubuklarında meydana gelebilecek ağırlık kaybı ölçüm yöntemidir (Yalçiner vd., 2012). c) Galvanik Pil Deneyi: Kaplama yapılmıș donatı çubukları arasındaki potansiyel farkın belirlendiği bir yöntemdir (Binici vd., 2012).

\subsection{Yöntem}

\subsubsection{Hızlandırılmış korozyon yöntemi}

Hızlandırılmış korozyon, elektrokimyasal yöntemlerle beton numunesi içerisinde bulunan donat1 çubuğunda meydana gelebilecek korozyon oluşumuna karşı göstereceği performansı izlemek amaciyla yapılan deney yöntemidir. Bu deney yönteminin uygulanmasında

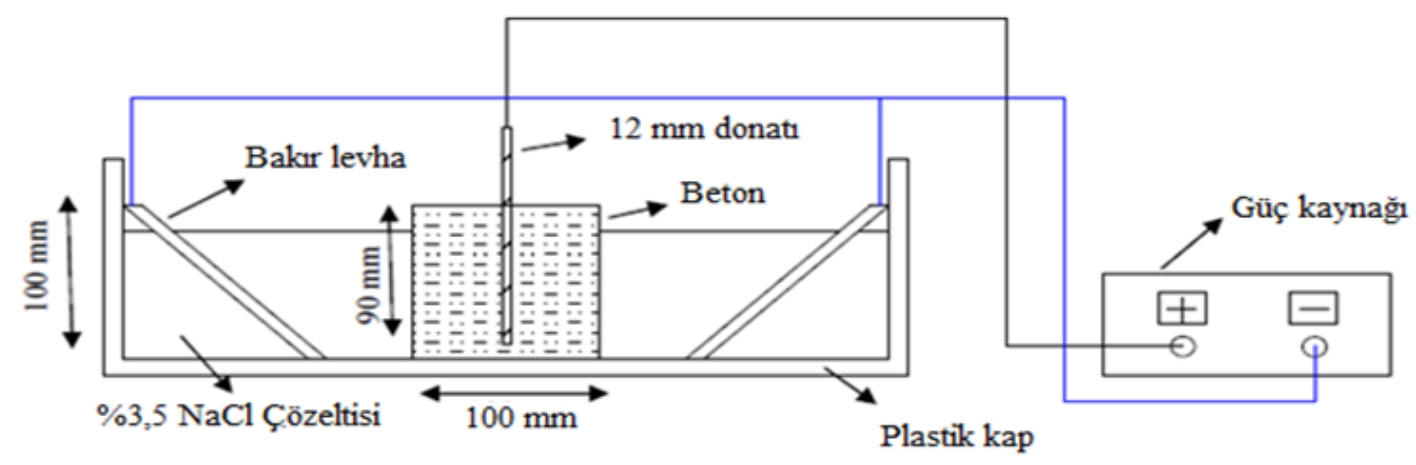

Şekil 2. Hızlandırılmış korozyon deneyi sistemi

Şekil 2'de de belirtildiği üzere $30 \mathrm{~V}$ gerilime sahip güç kaynağı. \%3.5 NaCl solüsyonu içerinde bakır plakalar ve deney numunesi yer almaktadır. $\mathrm{NaCl}$ solüsyonunun elektrolit donatının anot, katot davranış için de bakır levhaların eklenmesiyle bir devre oluşturulmuştur. Kullanılan deney yönteminde her bir örnek için $30 \mathrm{~V}$ sabit gerilim uygulanmıştır. Akım - zaman grafiğinin elde edilmesi amaciyla her 4 saatlik zaman diliminde akım değerleri kaydedilerek korozyon ürünü kontrol edilmiştir. Hızlandırılmış korozyon yöntemine maruz kalan beton örneği Şekil 3'te verilmektedir. 

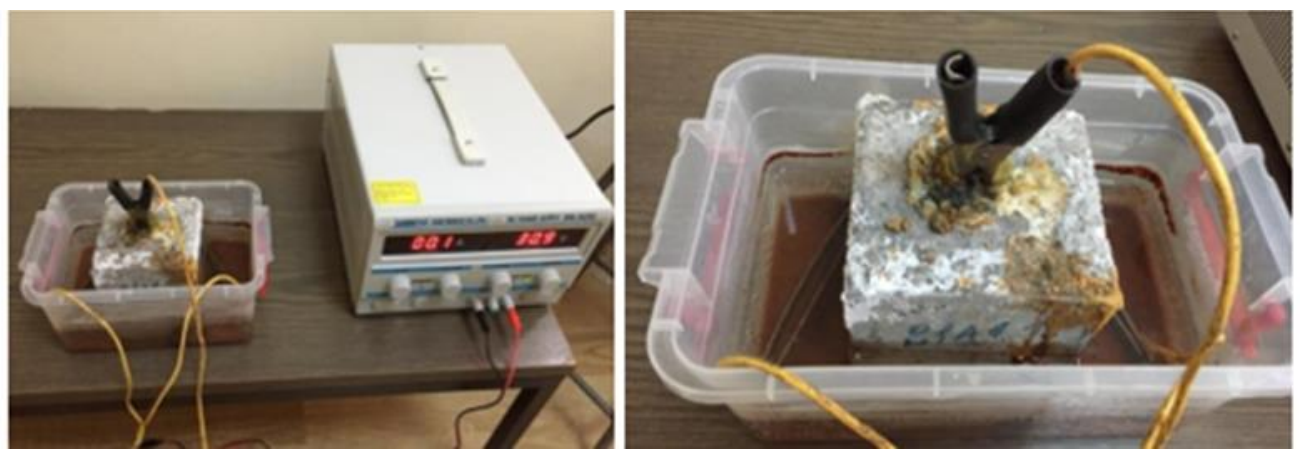

Şekil 3. Hızlandırılmış korozyon yöntemi uygulanan beton örneği

\subsubsection{Kütle kaybı yöntemi}

Hazırlanan donatıların yerleştirilmesi için TS 802 (2016) kullanılarak belirlenen karışım oranlarına göre numuneler hazırlanmıştır. Kalıplara yerleştirme işlemi TS EN 12390-2 'de ki esaslar dikkate alınmış ve özel bir başlık kullanılarak donatılar betonlara yerleştirilmiştir.

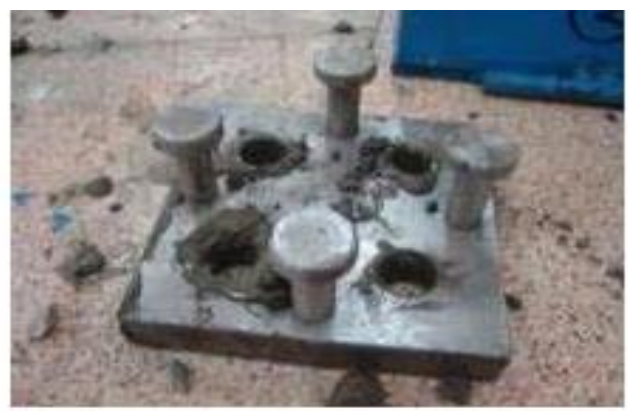

Her bir seriden C30 karışımına gömülmek üzere çelik çubuk numunesi hazırlanmıştır. 256 numune 6 aylık korozyon deneyi için hazırlanmıştır. Çubukların yerleştirilmesi için kullanılan özel başlık sayesinde donatılar eşit miktarda yanlardan 25 'er mm pas payına sahip olmaktadırlar. Yapılan özel başlık Şekil 4'de görülmektedir.

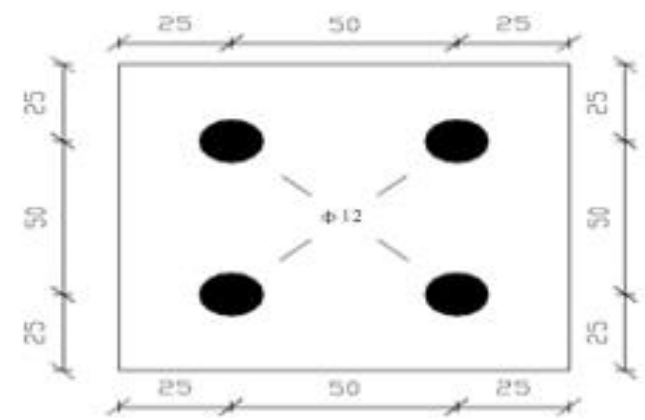

Şekil 4. Korozyon numuneleri için yaptırılan özel başlık ve kesit görünüşü

\subsubsection{Galvanik hücre yöntemi}

Çelik çubukların korozyona karşı göstermiş oldukları direnç değerlerini ölçmek amacıyla galvanik hücre metodu yöntemi kullanılmaktadır. $\mathrm{Bu}$ yöntemde; elektron alışverişinin gerçekleşmesi için elektrolit içine metal parçalar daldırılarak birbirlerine temas ettirilir. Temas eden parçalarda potansiyel fark meydana gelmektedir. Meydana gelen potansiyel fark ile metaller anot ve katot davranışları göstermektedirler. $\mathrm{Bu}$ değerler voltmetre ile kolaylıkla ölçülebilmektedir. Galvanik hücre yöntemi ile metaller arasında meydana gelebilecek potansiyel farkların ölçümü için boyutları ve çapları sırasıyla $10 \mathrm{~cm}-12 \mathrm{~cm}$ olan donatı çubukları oluşturulmuştur. $\mathrm{R}$ numunesi dışında hazırlanan donatı çubukları üzerine boya katkısı tek kat eklenmiş ve 24 saat laboratuvar şartlarında bekletilmiştir. Galvanik hücre yöntemi için hazırlanan donatı çubukları Şekil 5'de gösterilmektedir.

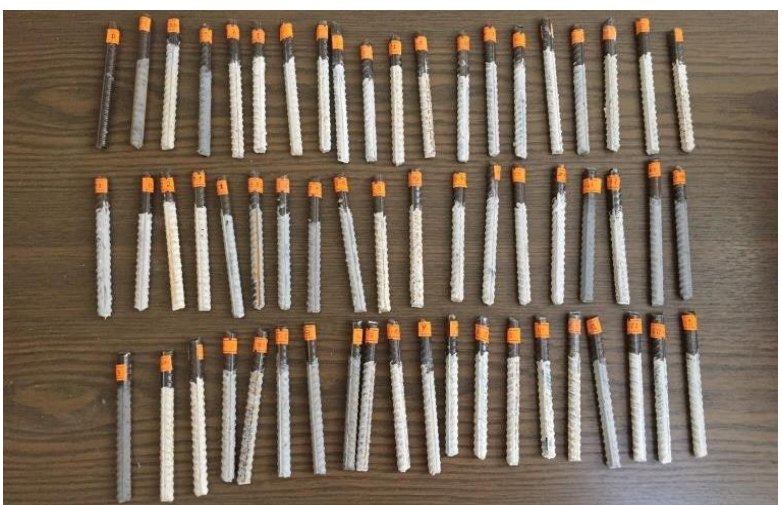

Şekil 5. Galvanik hücre yönteminde kullanılan donatı çubukları

Bakır levhalar elektrot sıvısının bulunduğu kapta voltmetreyle anot ve katot davranışlar gösterecek biçimde bağlandı. Kaplarda bulunun $\% 3.5 \mathrm{NaCl}$ solüsyonu etkisiyle çelik çubuklar ile bakır levhalar arasında meydana gelen potansiyel fark değerleri voltmetre aracillğ 1 ile okunarak kaydedilmiştir. Galvanik hücre metodu yönteminin donatılarda uygulanması Şekil 6'da verilmektedir. 


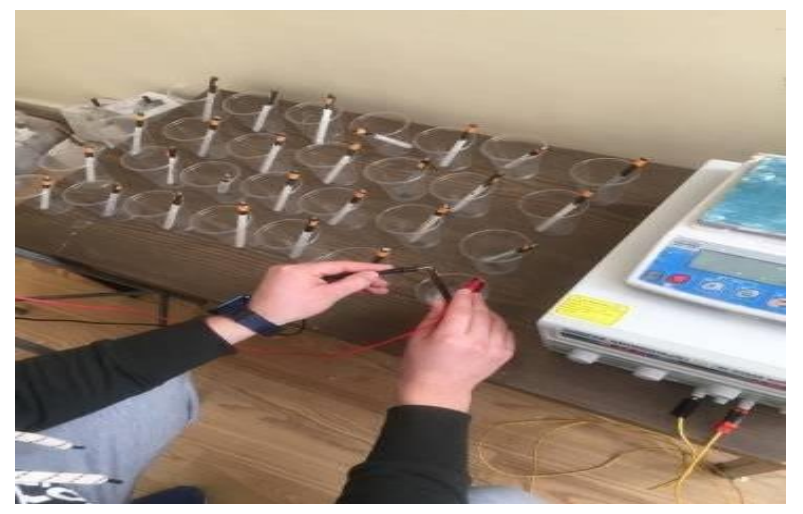

Şekil 6. Galvanik hücre yöntemi ile ölçüm yapılan donatı çubukları

\section{Bulgular}

\subsection{Hızlandırılmış korozyon deney sonuçları}

Hızlandırılmış korozyon deneyin kapsamında birçok veri elde edilmiștir. Numuneler gün içerisinde belirli saat aralıkları ile kontrol edilmiş üzerlerinden geçen akım değerleri kaydedilmiş ve değişikler sürekli olarak takip edilmiştir. Bu işlem 24 hafta en son numuneden korozyon ürünü elde edilinceye kadar sürdürülmüş son numunenin korozyon ürünü verisinin ardından bir sonraki ölçümle deney durdurulmuştur. Bu ölçüm değerleri Şekil 7 - Şekil 10’da verilmiştir.

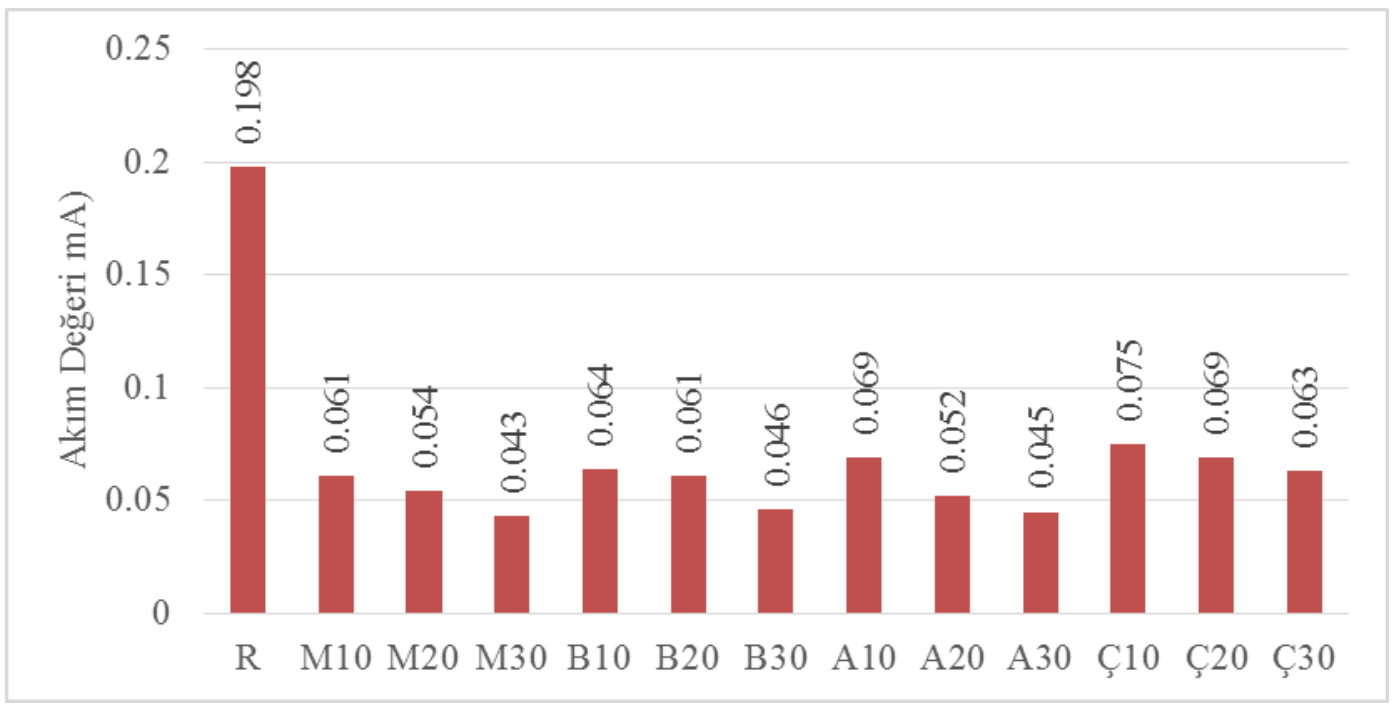

Şekil 7. Tarımsal atıklarla üretilen tekli karışımlarından geçen akım değerleri

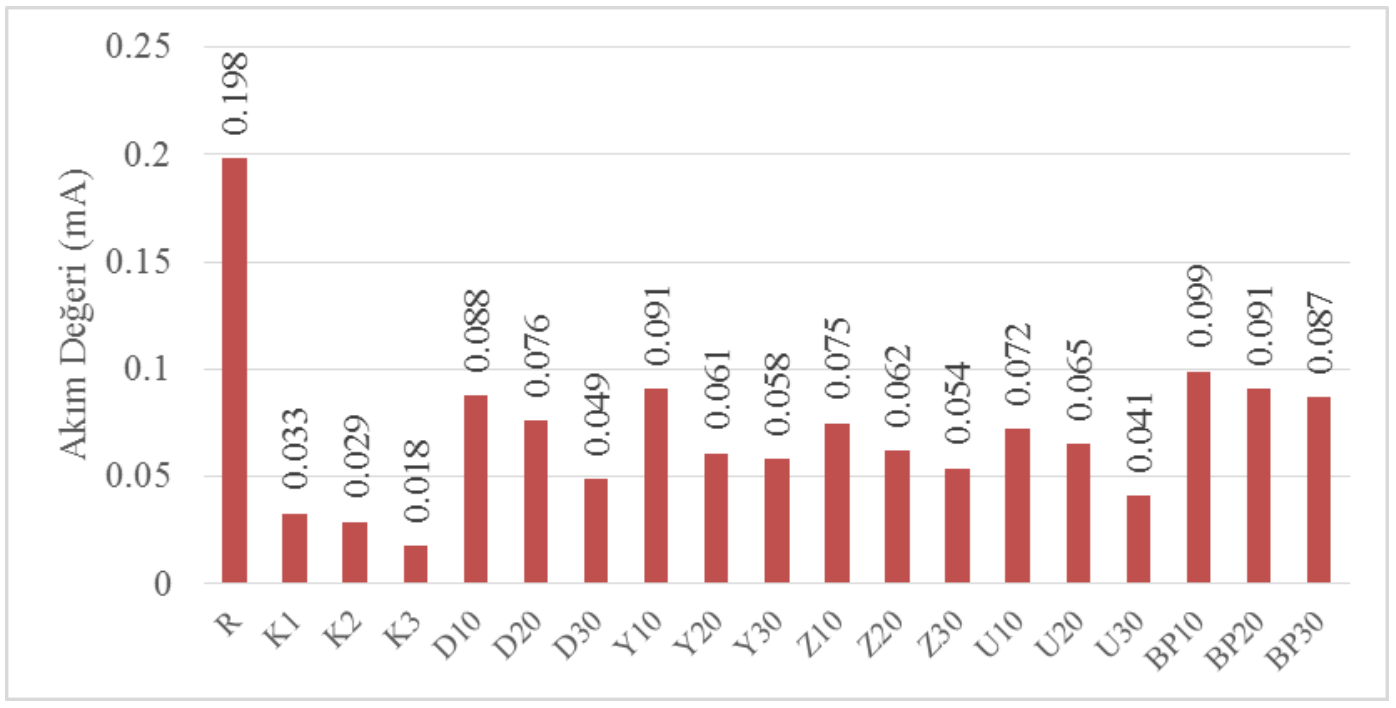

Şekil 8. Mineral katkılarla üretilen tekli karışımlarından geçen akım değerleri 


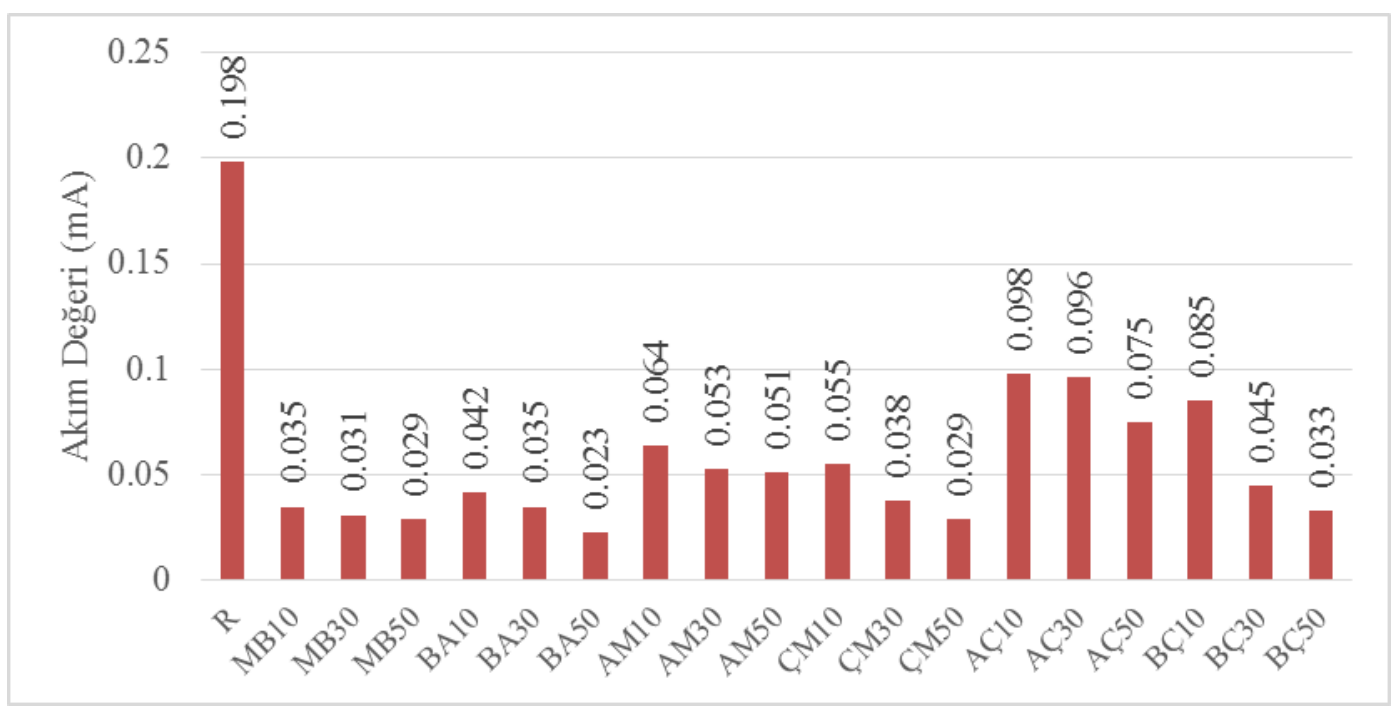

Şekil 9. Tarımsal atıklarla üretilen ikili karışımlarından geçen akım değerleri

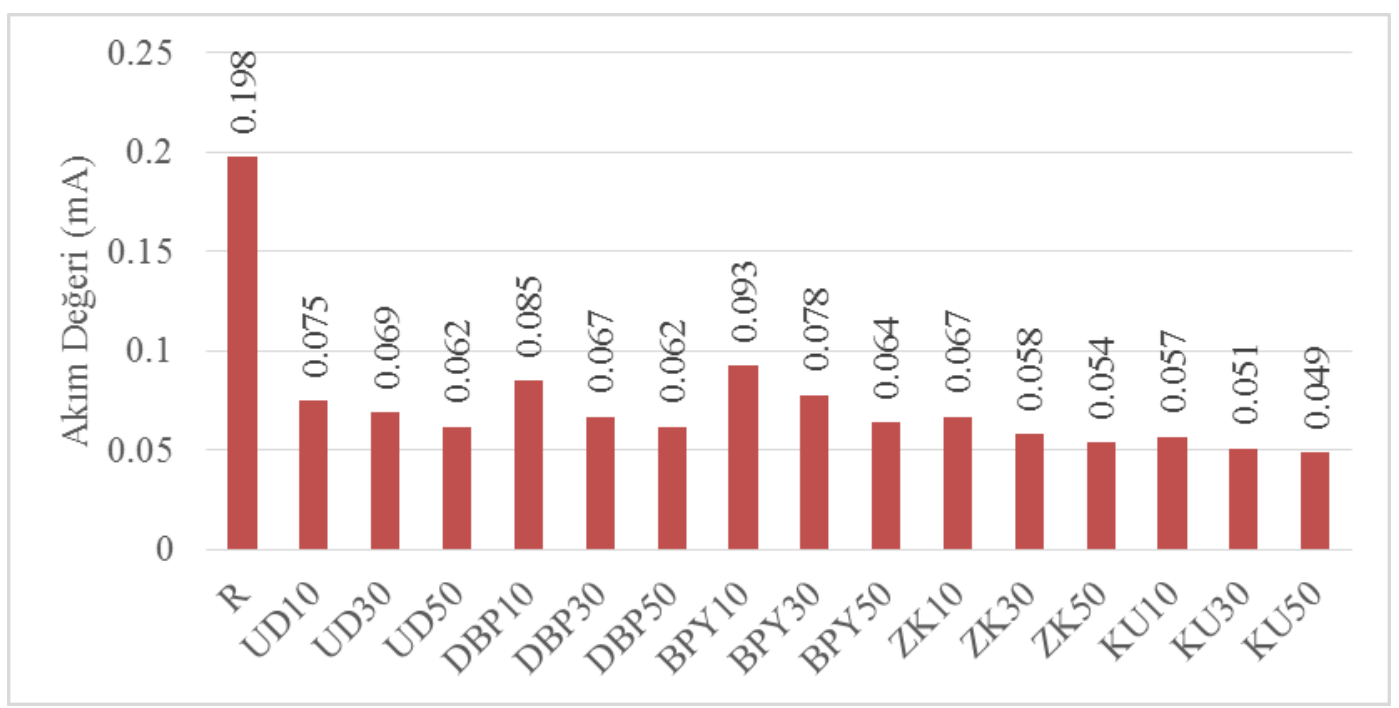

Şekil 10. Mineral katkılarla üretilen ikili karışımlarından geçen akım değerleri

Tarımsal atık külleri ve mineral katkılarla üretilen boyalarla kaplanan numunelerden geçen akım değerleri incelendiğinde referans numunesi üretilen numunelerin hepsinden genel olarak en yüksek akım değerine ulaşmıştır. Akımı değerinin diğer numunelerden fazla olması korozyon oluşum riskinin referans numunesinde olduğunun bir göstergesidir. Tarımsal atık küller ile üretilen tekli karışımlarda en düşük akımı çeken numune M30, ikili karışımlarda ise BA50 numunesidir. Mineral katkılarla üretilen tekli karışımlarda en düşük akımı çeken numune $\mathrm{K} 3$, ikili karışımlarda ise KU30 ile kaplanan numunedir. Deneyin başlangıcından bitimine kadar geçen akım değerleri incelendiğinde en düşük akımı çeken KU30 numunesidir. Her bir numune üzerinden geçen akım değerleri incelendiğinde $\mathrm{R}$ numunesi $0.198 \mathrm{~mA}$ akım çekerek korozyon riski en fazla numune olarak belirlenmiştir. Tarımsal atık kül katkılı tekli karışımlarla kaplanan M30 numunesi deney boyunca yaklaşı ortalama $0.043 \mathrm{~mA}$, ikili karışımlarla kaplanan BA50 numunesi $0.023 \mathrm{~mA}$ akım çekmiştir. Mineral katkılı tekli karışımlarla kaplanan K3 numunesi deney boyunca yaklaş1k ortalama $0.018 \mathrm{~mA}$, ikili karışımlarla kaplanan KU30 numunesi deney boyunca yaklaşı 0.049 $\mathrm{mA}$ akım çekmiştir.

\subsection{Kütle kaybı sonuçları}

Tarımsal atıklar ve mineral katkılar kullanılarak üretilen tekli ve ikili karışım katkılı boyalarla kaplanmış çelik çubuk numunelerin korozyon değerleri elde edilmiştir. Tekli karışım katkılı boyalarla üretilen donatıların kütle kaybı değerleri Şekil 11 ve Şekil 12'de. İkili karışım katkılı boyalarla üretilen donatıların kütle kaybı değerleri de Şekil 13 ve Şekil 14'de verilmektedir. 


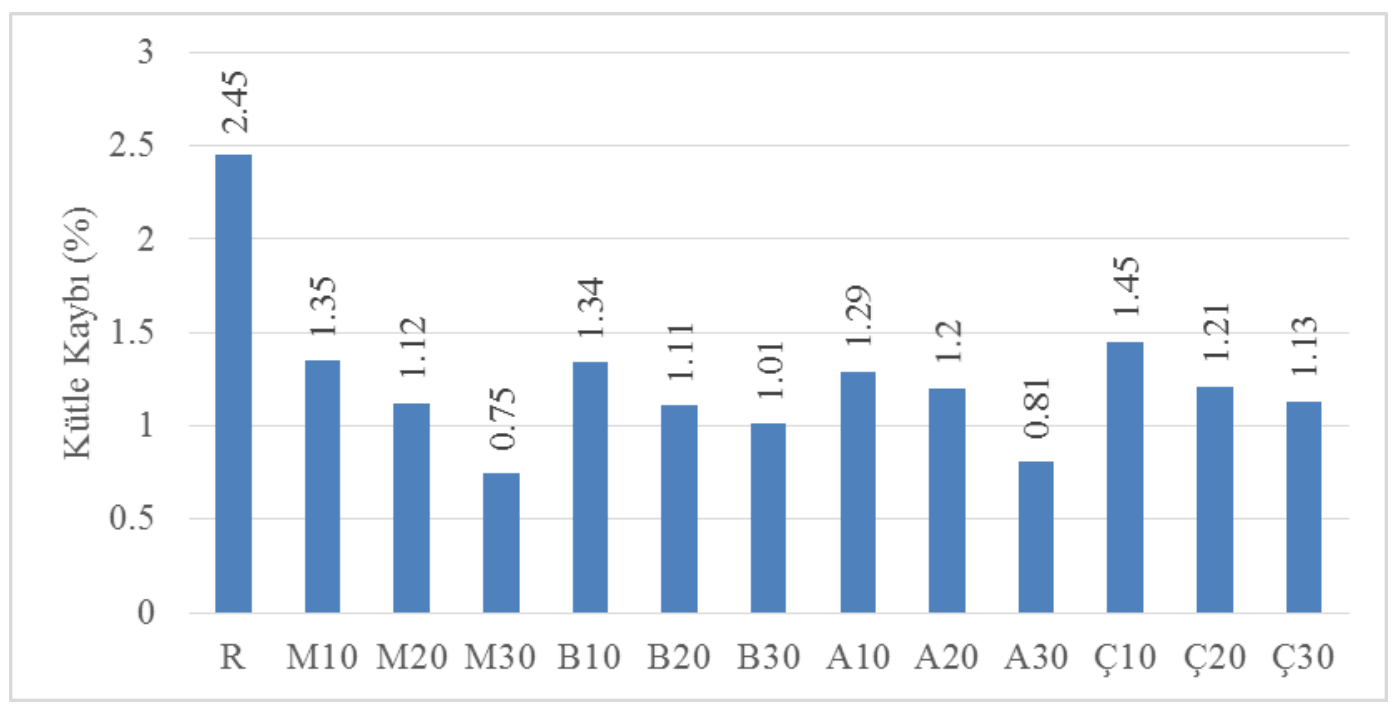

Şekil 11. Tarımsal atıklarla üretilen tekli karışımların donatı kütle kayıpları

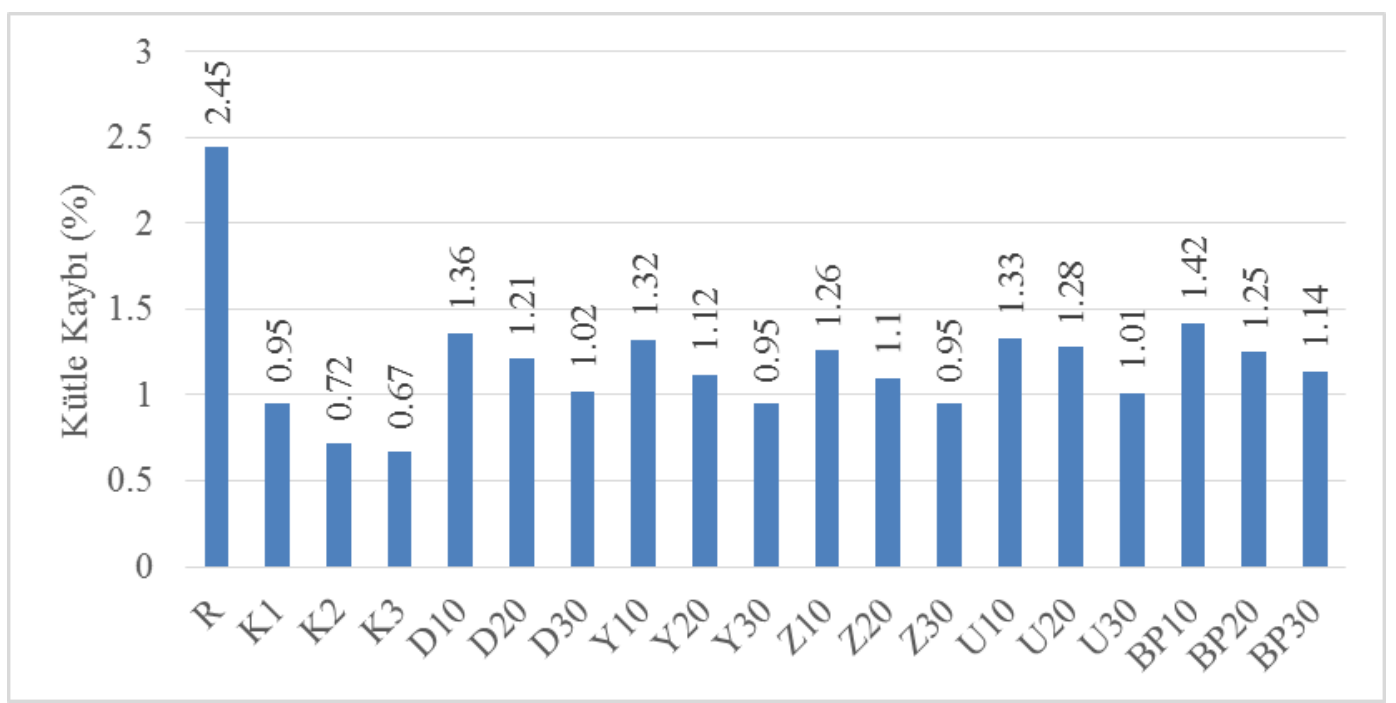

Şekil 12. Mineral katkılarla üretilen tekli karışımların donatı kütle kayıpları

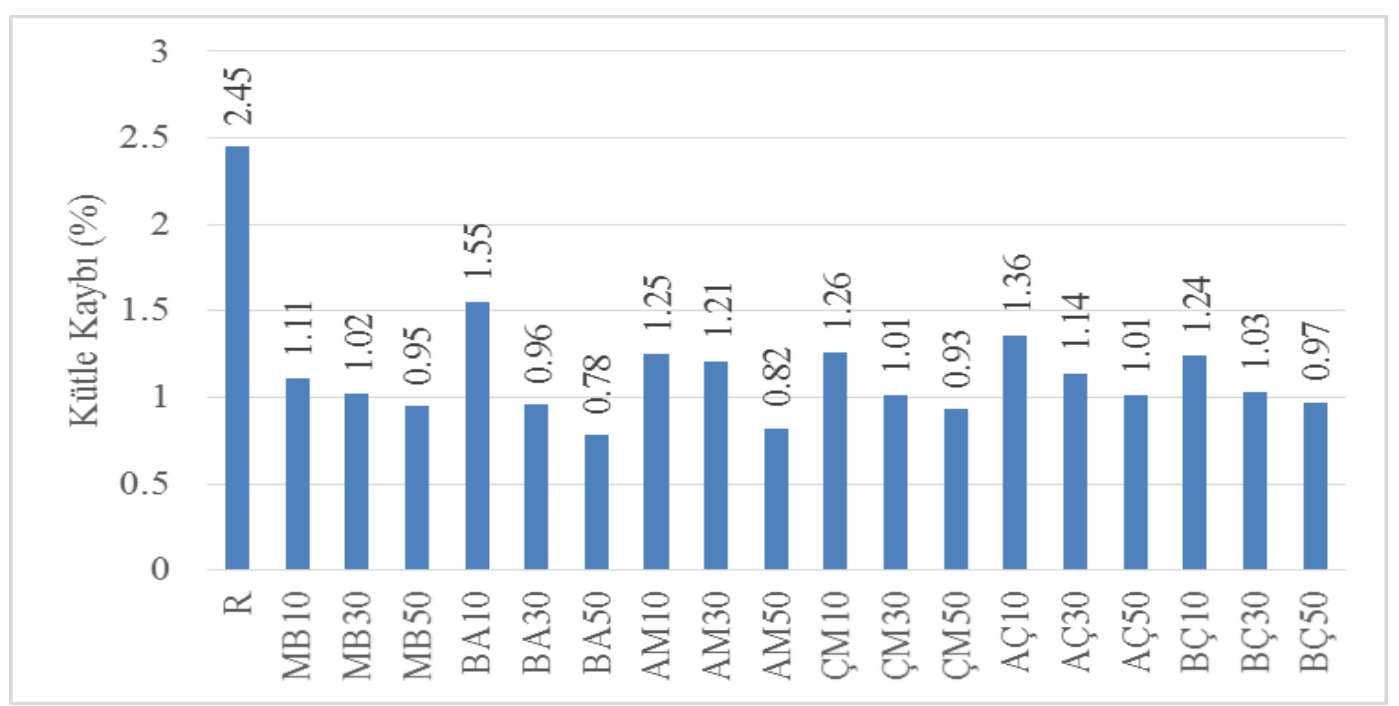

Şekil 13. Tarımsal atıklarla üretilen ikili karışımların donatı kütle kayıpları 


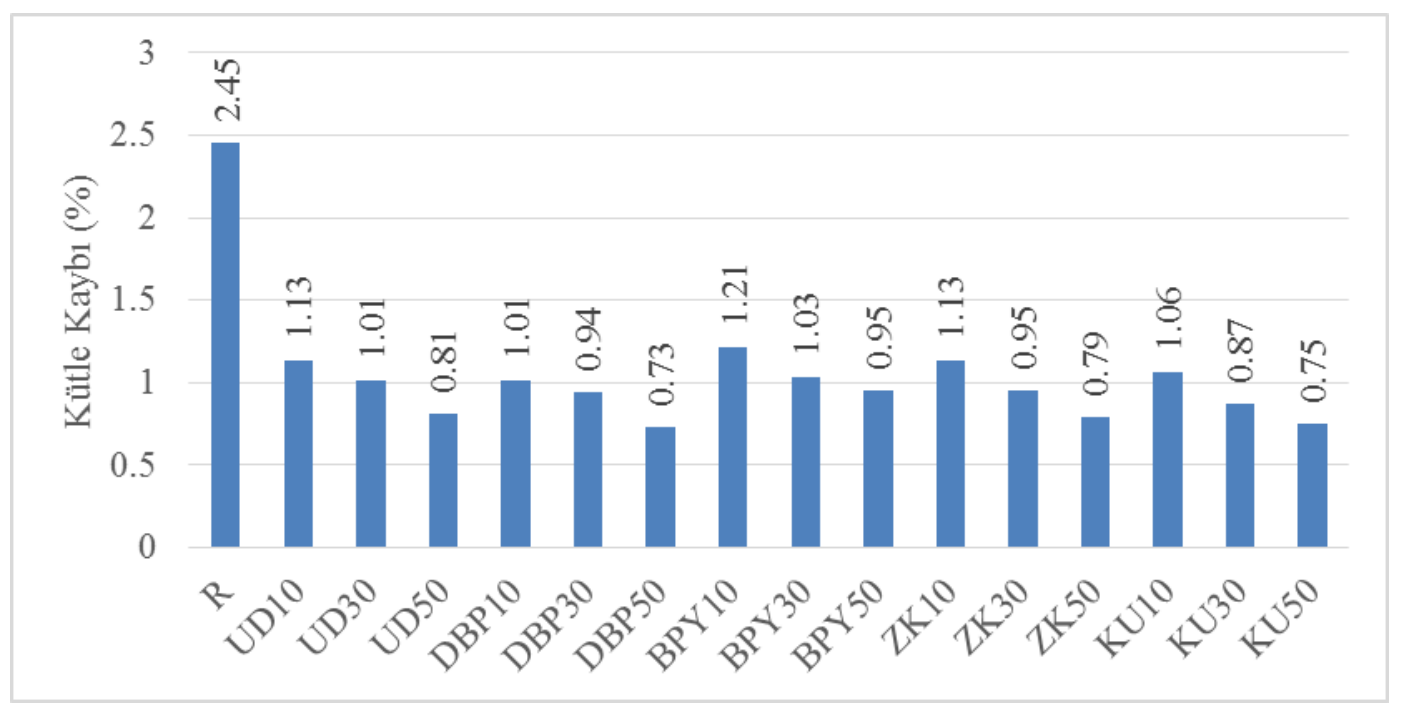

Şekil 14. Mineral katkılarla üretilen ikili karışımların donatı kütle kayıpları

Deney sonuçları incelendiğinde 180 günlük süre boyunca tuzlu su ortaminda bekletilen numunelerdeki çelik çubukların korozyona uğramasında referans dışında tarımsal atık ve mineral katkılar kullanılarak olușturulan kaplama malzemesinin donatı çubukları korozyona karşı korumada etkili olduğu görülmüştür. Genel itibariyle mineral katk1 kullanılan K1, K2, K3, ZK30, KU30 ve tarımsal atık kül katk1lı M30, A30, BA50 olan kaplama malzemeleriyle kaplanan numunelerde kütlece kaybın düşük olduğu görülmüştür. Bunun sebebi kolemanit katkısının ve tarımsal atık kül katkısının betonarme donatısının pasifliğini istikrarlı tutmasıdır. Bulunduğu bölgede betonun $\mathrm{Ph}$ seviyesinin sabit olarak kalmasina sebep olduğundan donatılar için koruma sağlamıştır. Kolemanit katkılı örneklerin donatı çubukları üzerinde korozyon oluşumu önleyici katkı sağladığı bilinmektedir (Yalçın, 1996).

\subsection{Galvanik hücre yöntemi deney sonuçları}

Korozyon sonuçlarının değerlendirilmesinde kullanılan galvanik hüre yöntemi uygulaması, $\mathrm{NaCl}$ solüsyon katkılı kaplarda donatı çubukları ile bakır levhalar arasında oluşacak potansiyel fark değerlerinin okunmasıdır. Galvanik hücre yöntemi deneyine ait sonuçlar Şekil 15- Şekil 18'de verilmiştir.

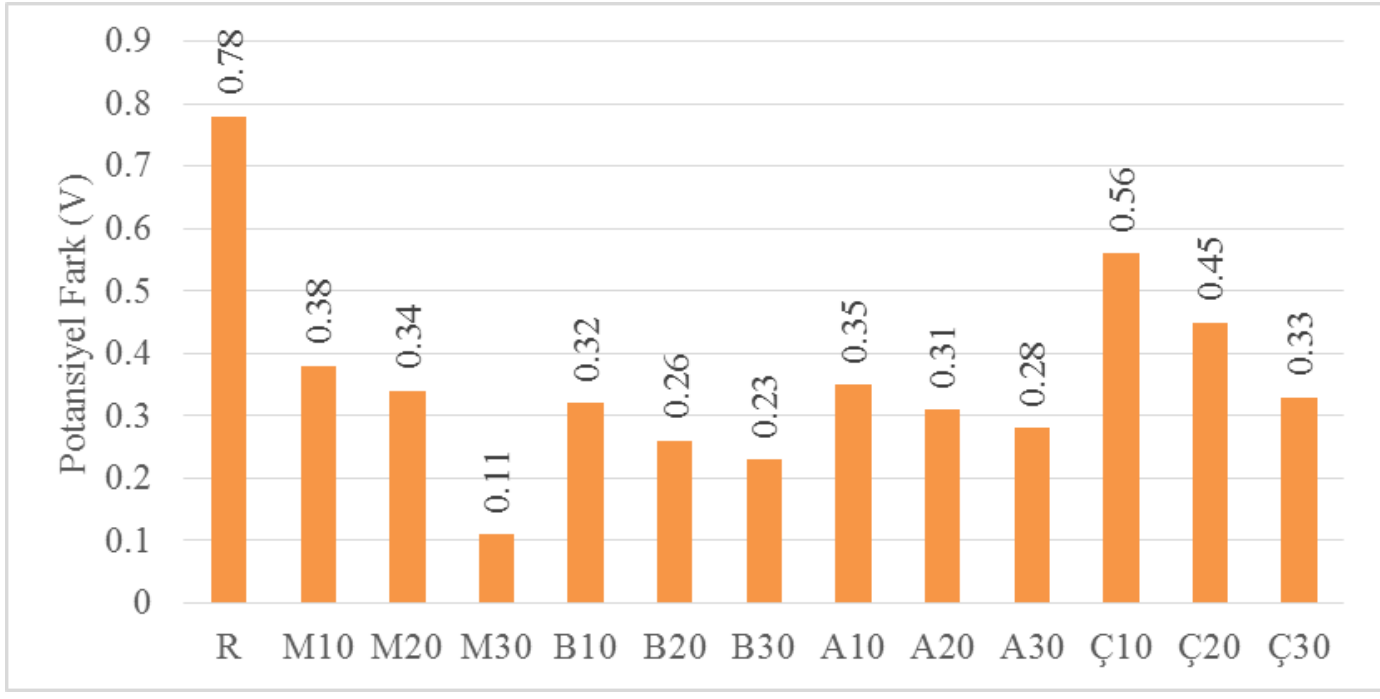

Şekil 15. Tarımsal atık kül katkılı tekli karışımların potansiyel fark değerleri 


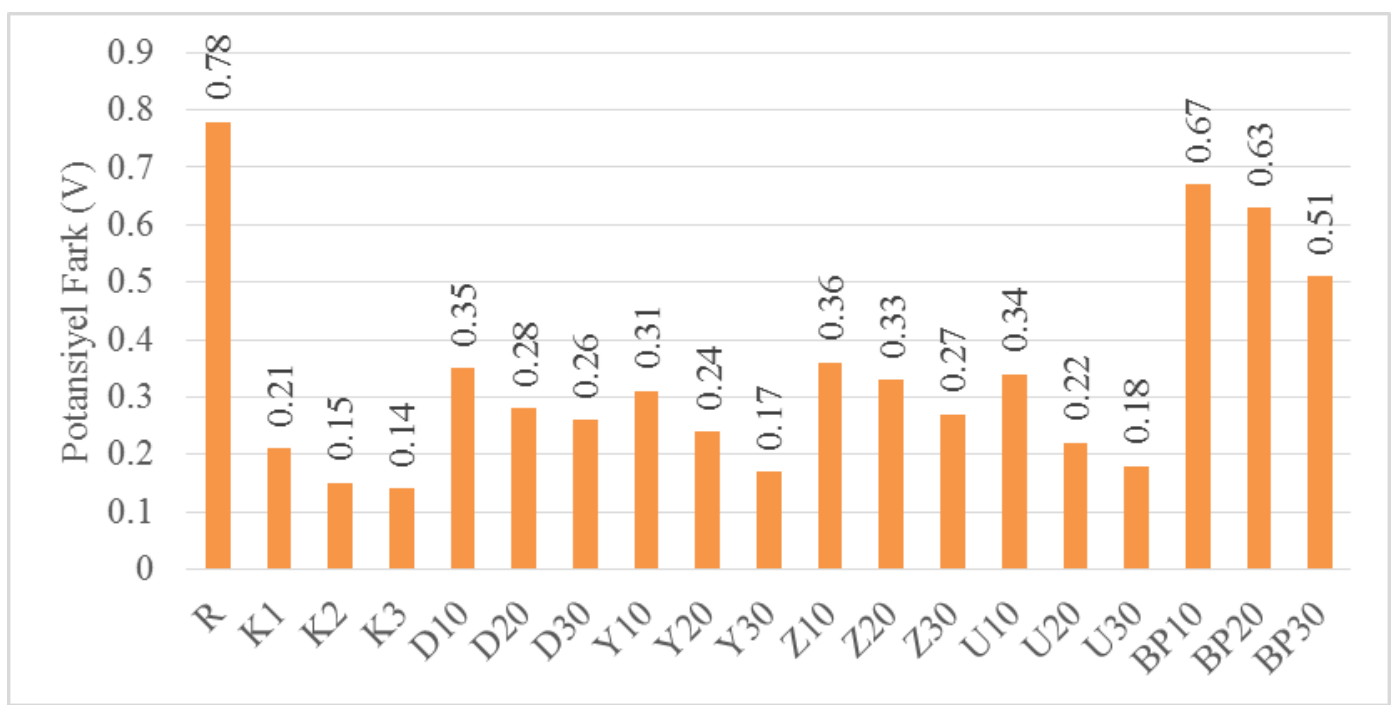

Şekil 16. Mineral katkılı tekli karışımların potansiyel fark değerleri

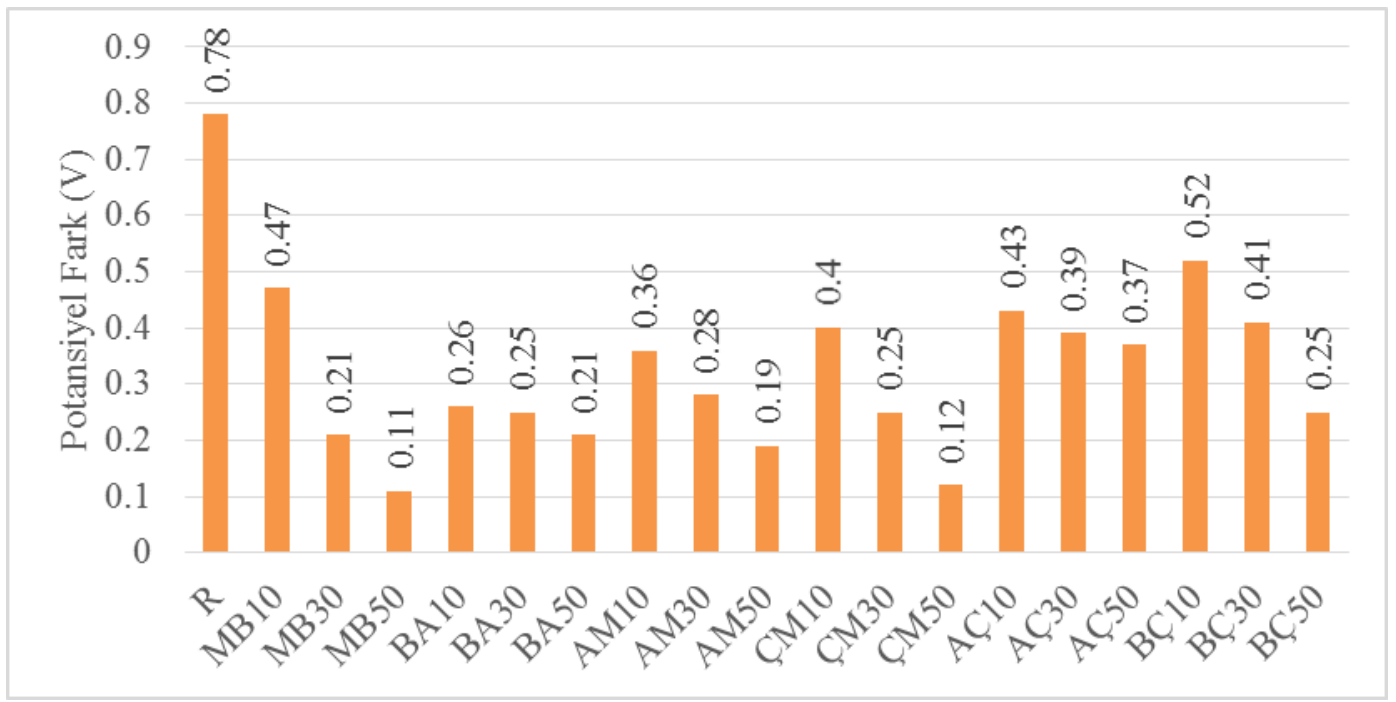

Şekil 17. Tarımsal atık kül katkılı ikili karışımların potansiyel fark değerleri

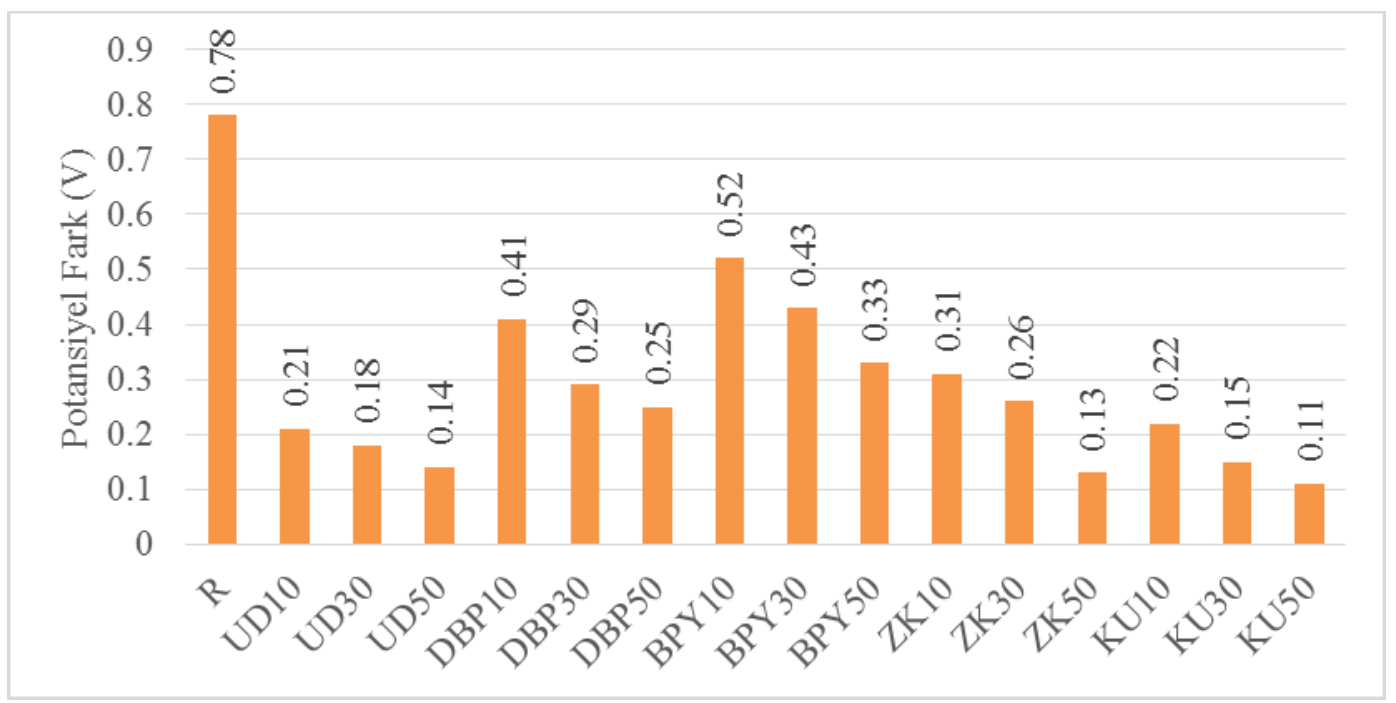

Şekil 18. Mineral katkılı ikili karışımların potansiyel fark değerleri 
Anot davranış olarak çelik numunelerin, katot davranış olarak bakır levhaların kullanıldığı deneyde en yüksek potansiyel farkı dış yüzeyi herhangi bir kaplamaya maruz kalmayan $\mathrm{R}$ numunesinde görülmüsstür. Bu değerlendirme ile en fazla tahribata, yani korozyona uğrayacak olan numune R numunesidir. Mineral katk1lı boyalarda kolemanit ile kaplama yapilan numunenin potansiyel farkının düşük çıkması korozyon oluşumunu engelleyici etkisinin görüldüğü söylenebilir. Tarımsal atık küllerle üretilen numunelerden M30 ve B30 katk1lı numunelerin potansiyel fark değerleri incelendiğinde sirasıyla $0.11,0.23$ değerleri okunmuş ve korozyon riskini azaltıcı etkisi gösterdiği söylenebilmektedir.
$M$ ve B katkılı tarımsal küllerin potansiyel farkının düşük olmasının sebebi kimyasal analizi ile açıklanabilir. Kolemanit katkı1ı numunelerin korozyon oluşumuna göstermiş olduğu direnci de elektrik iletkenliğinde göstermiş olduğu yalıtkan görevi ve elektron değerlerinin düşüklüğü ile açıklanabilir. Diğer minerallerin potansiyel farklarının kolemanitten yüksek olmasının sebebi kimyasal etkilere karşı koruma sağlayabilen mineral katkılar olmalarından ileri geldiği söylenebilir. Ayrıca pomza katkı1ı boyalarla üretilen numunelerin sonuçlarının da iyi çıkmamasının nedeni olarak da yine pomzanın boşluklu yapısı ile bağlantılı olduğu düşünülmektedir.

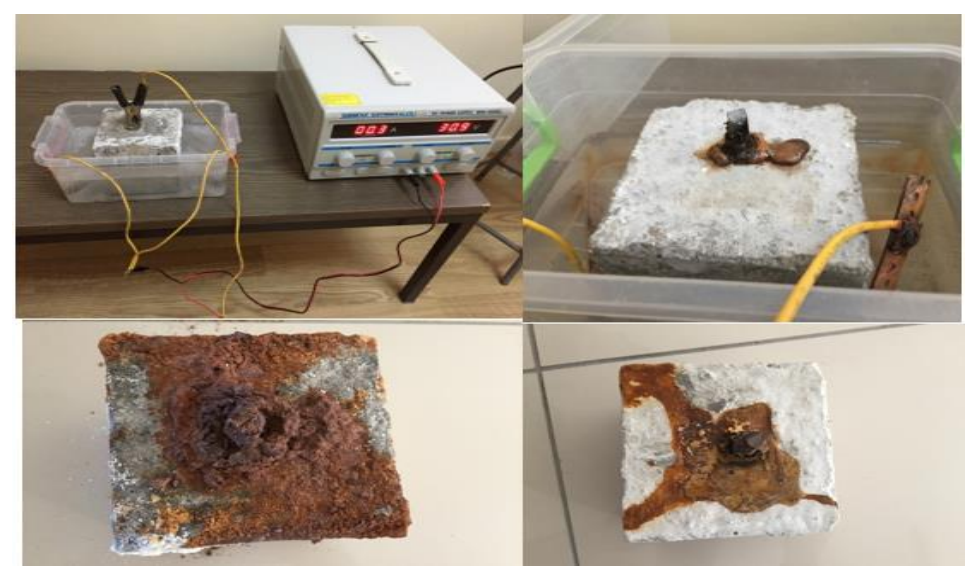

Şekil 19. Donatı çubuklarının korozyon oluşumları

\section{Tartışma ve sonuçlar}

Literatürde tarımsal atıkların ve minerallerin kaplama yöntemi olarak korozyona karş1 dirençlerinin araştırılması sınırlı sayıdadır. $\mathrm{Bu}$ ihtiyacın karşılanması amacıyla mısır, buğday, ayçiçeği, çınar yaprağı tarımsal atıkları ile kolemanit, diatomit, yüksek firın cürufu, zeolit, uçucu kül ve bazaltik pomza katkılarının tekli ve ikili karışımları ile üretilen boya malzemesi çelik donatı üzerine kaplama olarak uygulanmış ve ayrıca bu katkılar kullanılarak beton örnekleri üretilmiş korozyona karşı göstermiş olduğu direnç araştırılmış ve performansları değerlendirilmiştir.

•Hızlandırılmış korozyon yöntemine göre. Akım çekme sonuçlarına göre korozyon oluşum riskleri belirlenmiştir. Beton içerisine gömülü yüzeyi kaplı numunelerin akım çekme değeri yüksek olanlar korozyon oluşumuna uğrama riski en fazla, akım çekme değeri düşük olan numuneler ise korozyon oluşumuna uğrama riski az olarak belirlenmiştir. Tarımsal atık küller ile üretilen tekli karışımlarda \% 0.043 değeri ile en düşük akımı çeken korozyon oluşum riski en az numune M30, ikili karışımlarda \% 0.023 oranına sahip en düşük akımı çeken korozyon oluşum riski en az numune ise BA50 numunesidir. Mineral katkılarla üretilen tekli karışımlarda \% 0.018 değeri ile en düşük akımı çeken korozyon oluşum riski en az numune $\mathrm{K} 3$, ikili karışımlarda ise \% 0.051 değeri ile en düşük akımı çeken korozyon oluşum riski en az numune KU30 ile kaplanan numunedir. R dışındaki diğer numuneler ortalama akım çekme değerleri göstermiş ve korozyon oluşum riskleri $\mathrm{R}$ numunesine göre düşük çıkmıştır

•Kütle kaybı yöntemine göre; 180 günlük süre boyunca tuzlu su ortamında bekletilen numunelerdeki çelik çubukların korozyona uğramasında referans dışında tarımsal atık ve mineral katkılar kullanılarak oluşturulan kaplama malzemesinin donatı çubukları korozyona karşı korumada etkili olduğu görülmüştür. Tarımsal atık küller ile üretilen tekli karışımlarda $\% 0.75$ değeri ile en düşük kütle kaybı gösteren numune M30 katkılı numune olurken, ikili karışımlarda \% 0.78 ile en düşük kütle kaybı BA katkılı numune olmuştur.

Mineral katkılarla üretilen tekli karışımlarda \% 0.67 değeri ile en düşük kütle kayb1 gösteren numune K3 katk11 numune olurken, ikili karışımlarda $\% 0.73$ değeri ile en düşük kütle kaybı 
gösteren numune DBP50 katk1lı numune olmuştur. $\mathrm{R}$ dışındaki kaplama malzemeleriyle kaplanan numunelerde kütlece kaybın düşük, korozyon oluşum riskinin az olduğu belirtilmiştir.

- Galvanik pil deneyinde, en yüksek potansiyel farkı dolayısıyla korozyon oluşum riski diş yüzeyi herhangi bir kaplamaya maruz kalmayan $\mathrm{R}$ referans numunesinde görülmüştür. Tarımsal atık küller ile üretilen tekli karışımlarda \% 0.11 değeri ile en düşük potansiyel fark oranına sahip korozyona uğrama riski en az M30 numunesi olurken, ikili karışımlarda \%0. 11 değeri ile en düşük potansiyel fark oranına sahip korozyona uğrama riski en az MB50 katkılı numune olmuştur. Mineral katkılarla üretilen tekli karışımlarda \% 0.14 değeri ile en düşük potansiyel fark oranına sahip korozyona uğrama riski en az numune K3 katkılı numune olurken, ikili karışımlarda \% 0.11 değeri ile en düşük potansiyel fark oranına sahip korozyona uğrama riski en az numune KU50 katk1lı numune olmuştur.

-Yapılan tüm korozyon araştırmalarına göre mısır, buğday, ayçiçeği, çınar yaprağı tarımsal atıkları ile kolemanit, diatomit, yüksek firın cürufu, zeolit, uçucu kül ve bazaltik pomza katkılarının tekli ve ikili karışımları ile üretilen boya malzemeleri ve beton örneklerinin, korozyon oluşum riskini azaltıcı bir etki yaptığı bulunmuştur. Aynı zamanda tarımsal atık küllerin ve farklı mineral katkıların geçirimsiz beton üretiminde kullanılabilirliği belirlenmiştir.

Ayrıca, çalışmada kullanılan tarımsal atıklar ve mineral katkılar elde edilmesi kolay ve bol miktarda bulunan malzemelerdir. Farklı açılardan bakıldığ1 zaman yeni istihdam alanlarının oluşturulabilmesine fikir verecek bir çalışmadır. Korozyon önlemede kullanılan kaplama yöntemi teknolojik açıdan, ekonomik açıdan vb. değerlendirildiğinde diğer korozyon önleme yöntemleri arasında kullanım kolaylığı, uygulanabilirliği bakımından en avantajlı yöntemlerden birisidir. Sonuç olarak tarımsal atıklar ve diğer mineral katkılar kullanılarak üretilen kaplama malzemelerinin yenilikçi, alternatif, doğa dostu korozyonu önlemede etkili malzemeler olduklarını göstermişlerdir.

\section{Kaynaklar}

Abouhussien, A. A. and Hassan, A. A. A. (2014). Experimental and empirical time to corrosion of reinforced concrete structures under different curing conditions. Advanced. Civil Engineering. 1 - 9. https:// doi.org / 10.1155 / 2014 / 595743

Aksogan, O., Binici, H. and Ortlek., E. (2016). Durability of concrete made by partial replacement of fine aggregate by colemanite and barite and cement by ashes of corn stalk wheat straw and sunflower stalk ashes. Construction and Building Material, 106. 253-263. https://doi.org/10.1016/j.conbuildmat.2015.12.1 02

Badar, M. S., Patil, K., Bernal, A. S., Provis, L. J. and Allouche., N. E. (2014). Corrosion of steel bars induced by accelerated carbonation in low and high calcium fly ash geopolymer concretes. Construction and Building Materials, 61. 79-89.

Baradan, B., Yazıcı, H. ve Ün., H. (2002). Betonarme Yapılarda Kalıcılık (Durabilite). 1. Baskı. Dokuz Eylül üniversitesi Mühendislik Fakültesi Yayınları, 282-298.

Binici, H., Aksogan, O. and Durgun., M. Y. (2012). Corrosion of basaltic pumice. Colemanit, barite and blast furnace slag coated rebars in concretes. Construction and Building Materials, 37, 629$637 . \quad$ https://doi: 10.1016/j.conbuildmat.2012.07.030

Binici, H., Zengin, H., Zengin, G. and Yaşarer, F. (2008). The use of pumice as a coating for the reinforcement of steel against corrosion and concrete abrasions. Corrosion Science. 50. 2140-2148.

Çil, İ. (2006). Betonarme donatısında elektriksel yöntemlerle korozyon ölçümü. $D E U$ Mühendislik Fakültesi Fen ve Mühendislik Dergisi, 8. 59-63.

Coşgun, T. (2003). Ístanbul'da deprem sonrası yapılan incelemelerde karşılaşılan korozyon hasarı üzerine bir inceleme. 5.Ulusal Beton Kongresi, İstanbul, Türkiye.

Demirbaş, A., Öztürk, T. and Karataş, F. O. (2000). Long-term wear on outside walls of building sulphur dioxide corrosion. Cement Concrete Research. 31.3-6.

Doğan, M. (2000). Effects of İzmit and Düzce Earthquakes in Eskişehir. $\dot{I} \ddot{U}$.

Dorum, A. ve Yıldız, K. (2011). Yüksek dayanımlı betonlarda pomza ve zeolitin kullanılabilirliği. IMO Teknik Dergi. 345. 5335 - 5340.

Ergi, E., Bilgin. S. G., Zeybek, M. S. ve Asan., A. (2007). Endüstriyel Atık Katkılı Çimentoların Beton Dayanımı ve Donatı Korozyonuna Etkileri. 2. Yapılarda Kimyasal Katkılar Sempozyumu. Ankara.

Eskandari, H., Vaghefi, M. and Kowsaric., K. (2015). Investigation of Mechanical and Durability Properties of Concrete Influenced by Hybrid Nano Silica and Micro Zeolite Procedia. 
Materials Science, 11. 594 - 599. https://doi: 10.1016/j.mspro.2015.11.084

Gerengi, H., Kurtay, M. and Durgun, H. (2015). The effect of zeolite and diatomite on the corrosion of reinforcement steel in $1 \mathrm{M} \mathrm{HCl}$ Solution. Results in Physics, 5. 148-153. https://doi.org/10.1016/j.rinp.2015.05.003

Khatri, R. P., Sirivivatnanon, V. and Heeley, P. (2004). Critical polarization resistance in service life determination. Cement and Concrete Research. 34. 829-837. https://doi.org/10.1016/j.cemconres.2003.09.01 9

Küçük, B. (2000). Betonun Dayanım ve Durabilitesine Sağlayan Parametreler. Pamukkale Üniversitesi Mühendislik Fakültesi Mühendislik Bilimleri Dergisi. 6(1). 79-85.

Maaddawy, T.A. and Soudki., K. A. 2003. Effectiveness of impressed current technique to simulate corrosion of steel reinforcement in concrete. Journal of Civil Engineering. 15(1). 41-47. https://doi.org/10.1061/(asce)0899-1561(2003)

Najimi, M., Sobhani, J., Ahmadi, B. and Shekarchi., M. (2012). An experimental study on durability properties of concrete containing zeolite as a highly reactive natural pozzolan. Construction and Building Materials, 35. 1023-1033. https://doi.org/10.1016/j.conbuildmat.2012.04.0 38

Oyedepo, O. J., Oluwajana., S. D. and Akande., S. P. (2014). Investigation of properties of concrete using sawdust as partial replacement for sand. Civil Environmental. Research, 6 (2). 35-42. https://doi.org/10.1016 / j.ijsbe. 2016. 06.003

Pavlik, V. (1996). Corrosion of Hardened Cement Paste by Acetic and Nitric Acids. PART III: Influence of Water/Cement Ratio. Cement and Concrete Research, 26(3). 475-490. https://doi.org/10.1016/S0008-8846(96)85035-6

Pavlik, V. and Uncik., S. (1997). The rate of corrosion of hardened cement pastes and mortars with additive of silica fume in acids. Cement and Concrete Research, 27(11). 1731-1745. https://doi.org/10.1016/S0008-8846(97)82702

Pavlik, V. (2000). Effect of carbonates on the corrosion rate of cement mortars in nitric acid. Cement and Concrete Research. $30 . \quad 481-489$. https://doi.org/10.1016/S0008-8846(00)00201-5

Sakr, K. (2005). Effect of cement type on the corrosion of reinforcing steel bars exposed to acidic media using electrochemical techniques. Cement and Concrete Research, 35. 1820-1826. https://doi.org/10.1016 / j. cemconres. 2004. 10. 015
Sancak, E., ve Çoban., Ö. (2014). Olivin atıklarının betonda kullanımının betonarme donatısının korozyon özelliklerine etkisi. S. Ü. Müh. Bilim ve Teknik Dergisi. 2(4). https://doi.org/10.15317/Scitech.2014410339

Sisman, C. B. and Gezer., E. (2011). Effects of rice husk ash on characteristics of the briquette produced for masonry units. Scientific Research and Essays. 6(4). 984-992. https://doi.org/10.5897/SRE10.1136

Turkish Standards Institute. (2016). Design of Concrete Mixes. (TS 802) Ankara, Turkey.

Uysal, M. (2006). CrN. Tin kaplanmış ve kaplanmamış AISI 304 paslanmaz çeliğinin korozyon özellikleri. Yüksek Lisans Tezi. Gazi Üniversitesi Fen Bilimleri Enstitüsü. Ankara.

Vesely, D., Kalendova., A. and Kalenda., P. A. (2010). Study of diatomite and calcined kaoline properties in anticorrosion protective coatings. Progress in Organic Coatings. 68. 173-179. https://doi.org/10.1016/j.porgcoat.2010.02.007

Yalçın, S. (1996). The Inhibitive Effect of Colemanite Added Cement on the Corrosion of Reinforcing Steels. M.Sc. Thesis. Gazi University. Institute of Science and Technology. Ankara

Yalçın, H. ve Koç., T. (1999). Katodik Koruma, Palme Yayınlarl, 1(2). 269-287.

Yalçın, S. (1996). Kolemanitli çimentoların betonarme demirlerinin korozyonu üzerine inhibitif etkisi. Yüksek Lisans Tezi. Gazi Üniversitesi Fen Bilimleri Ensititüsü, Ankara.

Yalciner, H. Eren., O. and Sensoy., S. (2012). An experimental study on the bond strength between reinforcement bars and concrete as a function of concrete cover. Strength and corrosion level. Cement and Concrete Research. 42. 643-655. https://doi.org/10.1016/j.cemconres.2012.01.00 3

Yeau, K. Y. and Kim., E. K. (2005). An experimental study on corrosion resistance of concrete with ground granulate blast - furnace slag. Cement and Concrete Research, 35. 1391 - 1399. https:// doi.org / 10. 1016 / j. cemconres. 2004. 11. 010

Yıldız, K. and Uğur., O. L. (2009). Examination of durablity of high performance concrete (hpc) that has been subjected to $\mathrm{MgSO}_{4}$ and $\mathrm{NaCI}$ corrosion against freezing and thawing. Scientific Research and Essay 4 (9). 929-935.

Yıldız, K.ve Demirel., C. (2014). $\mathrm{MgSO}_{4}$ etkisine maruz rijit yol kaplamalarında pomza ve zeolit katkılı betonun kullanılabilirliği. Politeknik Dergisi. 17(1). 23 - 29. https://doi.org/10.2339/2014. 